\title{
Political, economic and environmental crisis in Northern Ireland: the true cost of environmental governance failures and opportunities for reform
}

\author{
Ciara Brennan, * \\ RAY PURDY ${ }^{\dagger}$
}

AND

Peter Hjerp $\neq$

\begin{abstract}
Decades of systemic failure to take environmental protection seriously has brought Northern Ireland to the brink of environmental, and now political and economic disaster. This article will consider the reasons why environmental governance in this jurisdiction has continued to be so problematic and the cost of government failure in this context for the people of Northern Ireland. It will set out the environmental, economic and socio-political consequences of the epic failures of successive devolved administrations to take environmental governance seriously, to respond to critiques of the performance of the environmental regulator and to ensure the effective enforcement of environmental law. Finally, it will consider options for dealing with this ongoing problem in a turbulent political environment where collapsing political institutions at Stormont and wider constitutional issues associated with the UK's plans to leave the EU may continue to stymie reform or present a unique opportunity to reinvent environmental governance and begin the process of remedying the damage caused by years of neglect.
\end{abstract}

Keywords: environmental governance; Northern Ireland; enforcement; regulation; waste crime.

\section{Introduction}

$\mathrm{R}^{\mathrm{c}}$ ecent scandals including the Renewable Heat Incentive (RHI) debacle ${ }^{1}$ and the discovery of illegal dumping on a massive scale ${ }^{2}$ have catapulted Northern Ireland's

* Lecturer in Law, Newcastle Law School, University of Newcastle.

$\dagger$ Senior Research Fellow in Law, Faculty of Law, University of Oxford.

‡ Founder, Ecocentric Consulting.

1 The RHI scandal and its implications will be discussed below, but essentially involved the mismanagement and alleged corruption of a funding scheme designed to incentivise the installation of renewable heat technologies (particularly wood-pellet stoves). A failure to apply proper cost controls has resulted in a predicted overspend of hundreds of millions of pounds. The scheme was delivered by the (then) Department of Enterprise, Trade and Investment from 2012 until its suspension in 2016 and the departmental minister who oversaw its implementation was Arlene Foster - First Minister when the scandal broke in late 2016. For an overview of the RHI scheme and key dates in the timeline see 'Q\&A: What is the Renewable Heat Incentive (RHI) Scheme' BBC News (13 December 2016) <www.bbc.co.uk/news/uk-northern-ireland-38307628> and Thomas Muinzer, 'Incendiary Developments: Northern Ireland's Renewable Heat Incentive and the Collapse of the Devolved Government' (March/April 2017) 99 UKELA E-Law 18.

2 Ciara Brennan, 'The Enforcement of Waste Regulation in Northern Ireland: Deterrence, Dumping and the Dynamics of Devolution' (2016) 28(3) Journal of Environmental Law 471-96. Discoveries of more illegal dumps continue to be made, and in early 2017 the Irish News reported that the NIEA was currently 
environmental governance failures into the public eye. The financial implications of these failures - which extend far beyond recent news headlines - are so epic in scale that they have played a key role in the destabilisation of Stormont's political institutions and now threaten the economic viability of the state. ${ }^{3}$ To many the impending crisis is no surprise and the problematic nature of environmental governance in Northern Ireland has been well documented over the last 30 years. Official scrutiny bodies such as the House of Commons Environment Select Committee, ${ }^{4}$ Northern Ireland Audit Office (NIAO), ${ }^{5}$ the Northern Ireland Affairs Committee (NIAC), ${ }^{6}$ the Public Accounts Committee (PAC) ${ }^{7}$ and the Criminal Justice Inspectorate (CJI $)^{8}$ have all published reports that have highlighted serious deficiencies both in how arrangements for environmental governance have been designed and how environmental regulation has been delivered. There have also been high-level governance reviews (commissioned by both the environmental non-governmental organisation (ENGO) community and government) which have set out clear and achievable options for reform. ${ }^{9}$ For over a decade Northern Ireland's ENGO community has campaigned without success for an independent environmental regulator to enhance the protection of the jurisdiction's natural resources. ${ }^{10}$ Academic analysis has highlighted significant issues with Northern Irish environmental law and its implementation. ${ }^{11}$ Even the

( $n 2$ continued) investigating over 700 illegal dumping incidents involving an estimated 500,000 tonnes of waste. See, John Monaghan, 'More than 700 Live Investigations into Illegal Dumping in Northern Ireland' Irish News (Belfast, 4 January 2017) <www.irishnews.com/news/2017/01/04/news/more-than-700-live-investigationsinto-illegal-dumping-in-northern-ireland-862958/>.

3 The extent to which the RHI scandal caused the collapse of the devolved government is disputed. Sinn Féin's narrative characterises RHI (specifically Arlene Foster's refusal to step aside as First Minister while the issues with RHI were investigated) as the 'straw that broke the camel's back', but DUP policy decisions relating to Brexit, legacy issues, cutting of Irish Language funding, the delay in introducing an Irish Language Act, the failing health of Sinn Féin party leader Martin McGuinness and worsening DUP/Sinn Féin relations throughout 2016 were also clearly significant factors. The DUP disputes any wrongdoing on the part of Arlene Foster and, at the time of writing, the matter is due to be investigated via public inquiry. See Chris Page, 'Stormont: All You Need to Know about NI's Latest Political Crisis' BBC News (16 January 2017) <http://www.bbc.co.uk/news/uk-northern-ireland-38612860>.

4 House of Commons Select Committee on the Environment, Environmental Issues in Northern Ireland (First Report of the Environment Committee (Rossi Report) HC 1990-91, 39).

5 NIAO, Control of River Pollution in Northern Ireland (HC 1997-98, 693); NIAO, Areas of Special Scientific Interest (HC 2003-2004, 499); NIAO, Northern Ireland's Waste Management Strategy (HC 2005-06, 88).

6 House of Commons NIAC, Waste Management Strategy in Northern Ireland (HC 2004-05, 349-I).

7 Northern Ireland Assembly PAC, Control of River Pollution in Northern Ireland (Third Report 2001) $<$ http://archive.niassembly.gov.uk/public/reports/report3-00r.htm>.

8 CJI, Enforcement in the Department of the Environment (2007) <www.cjini.org/getattachment/6e35e56d-68e541d3-b099-c33586abf0dd/Enforcement-in-the-Department-of-Environment.aspx>; CJI, Enforcement in the Department of the Environment Northern Ireland: A Follow Up Review of Inspection Recommendations (2011) <www.cjini.org/CJNI/files/d7/d71473bc-2dc9-4ff5-b957-d410ff851852.pdf> 9; CJI, A Review of the Northern Ireland Environment Agency's Environmental Crime Unit (2015) < www.cjini.org/getattachment/776ee5fc-b3c04759-8fbe-18a72a8f31e5/A-review-of-the-Northern-Ireland-Environment-Agenc.aspx $>35$.

9 Richard Macrory, Transparency and Trust: Reshaping Environmental Governance in Northern Ireland (UCL Press 2004) and Tom Burke, Gordon Bell and Sharon Turner, Foundations for the Future: The Review of Environmental Governance (2007) <www.ukela.org/content/doclib/135.pdf>.

10 For a detailed discussion of this campaign, see Sharon Turner and Ciara Brennan, 'Modernising Environmental Regulation in Northern Ireland: A Case Study in Devolved Decision Making' (2012) 63 Northern Ireland Legal Quarterly 509.

11 Ibid and e.g. Sharon Turner, 'Transforming Environmental Governance in Northern Ireland: Part One: The Process of Policy Renewal' (2006a) 18 Journal of Environmental Law 55; Sharon Turner, 'Transforming Environmental Governance in Northern Ireland Part Two: The Case of Environmental Regulation' (2006b) 18 Journal of Environmental Law 245; Sharon Turner, 'The Review of Environmental Governance in Northern Ireland' (2009) 2 Environmental Law Review 10-16; Brennan (n 2). 
environmental regulator has commissioned reports which have identified significant problems with its own performance. ${ }^{12}$ Perhaps the most damning indictments of the current governance systems have come from within government itself. One former Environment Minister, Alex Attwood, described the structures of the Northern Ireland Environment Agency (NIEA) in 2013 as not being fit for purpose. ${ }^{13}$ Another recent (former) Environment Minister, Mark H Durkan, said in 2015 that the present environmental governance models were in need of radical review and needed to be replaced quickly. ${ }^{14}$ However, despite evidence of serious regulatory dysfunction stretching back over three decades, unacceptable levels of non-compliance with environmental law and significant degradation of environmental quality, Northern Ireland's political class, as a whole, ultimately seems unwilling or unable to actually instigate any real change.

To some degree, the relegation of environmental concerns down the list of political imperatives in societies emerging from conflict is not surprising and has been recognised in other jurisdictions. ${ }^{15}$ However, 20 years after the Good Friday Agreement and in the face of a long history of warnings, criticism and debates on this issue in the intervening years, failure to engage with the need for effective environmental governance and respond with meaningful reform now seems difficult to justify. ${ }^{16}$ With the fall-out from the RHI scandal still looming over Northern Ireland's increasingly fragile political institutions and as the financial legacy of the years of regulatory neglect of the environment begins to become clear, Northern Ireland's taxpayers will ultimately now have to pay the price for the government's failure to protect their environment. However, amidst ongoing negotiations about Northern Ireland's political future, the issue of environmental governance could now be 'back on the table'. Faced with dramatic political and economic uncertainty in the wake of the Brexit vote and Stormont's collapse, a unique moment in time may have been created where there are opportunities to reform environmental governance structures, remould political attitudes to the environment and set in place a plan for full-scale renovation of Northern Ireland's approach to environmental protection. On the other hand, continued sidelining of these issues will have serious implications for decades to come.

This article will unravel the complexities of the environmental governance debate in Northern Ireland. It will firstly consider characteristics of 'good' environmental governance and set out an analytical framework that can be used to assess this quality and

12 Christopher Mills, A Review of Waste Disposal at the Mobuoy Site and the Lessons Learnt for the Future Regulation of the Waste Industry in Northern Ireland (Mills Report, DOE 2013).

13 Northern Ireland Assembly, Private Members Business, 21 January 2013 <http://www.theyworkforyou.com/ni/?id=2013-01-21.7.1>.

14 Northern Ireland Executive, 'Durkan Opens Debate for an Independent Environment Protection Agency' (Press Release, 22 September 2015) < https://ciwm-journal.co.uk/ni-proposes-independent-environmentprotection-agency/>.

15 E.g. Ken Conca and Jennifer Wallace, 'Environment and Peacebuilding in War-torn Societies: Lessons from the UN Environment Programme's Experience with Post-Conflict Assessment' (2009) 15(4) Global Governance: A Review of Multilateralism and International Organizations 485-504. For discussion of the impact of the conflict on environmental governance in Northern Ireland, see Sharon Turner and Karen Morrow, Northern Ireland Environmental Law (Gill \& Macmillan 1997); Karen Morrow and Sharon Turner, "The More Things Change, the More They Stay the Same? Environmental Law, Policy and Funding in Northern Ireland' (1998) 10(1) Journal of Environmental Law 41-59.

16 One of the UK's foremost environmentalists argued in 2015 that Northern Ireland should no longer use its troubled past as an excuse for failings over the environment. Jonathon Porritt said on the BBC that 'while there had been a justifiable focus on the political process, things needed to change. There's no excuse any longer for relegating the environment to a second-division issue.' 'Jonathon Porritt: Troubles "No Excuse for Environmental Failings"” BBC News (7 June 2015) <www.bbc.co.uk/news/uk-northern-ireland-33025054>. 
facilitate an evaluation of the degree of divergence from this model in Northern Ireland. The article will then identify the core problems with the current environmental governance arrangements, drawing from documented evidence of regulatory and policy dysfunction stretching back over 30 years which reflects an unequivocal political failure to take the protection of the environment seriously in this jurisdiction. Three key themes which have featured most prominently in the governance debate in this jurisdiction will be considered: problematic environmental regulation structures; outdated or ineffective environmental law and policy; and unsatisfactory delivery of environmental regulation in practice. The analysis will then move on to examine the environmental impact, economic risks and consequences and political and social implications of weak environmental governance. The impact of political developments and, in particular, some of the potential threats and opportunities attached to the unfolding Brexit situation will then be explored. Finally, mechanisms through which environmental protection efforts in Northern Ireland can be improved, but also insulated from the political maelstrom in which the jurisdiction is currently engulfed, will be proposed. The article will conclude by mapping a pathway through which an ambitious programme of environmental governance reform in Northern Ireland could be achieved.

\section{Evaluating environmental governance 'success'}

Environmental governance is a concept that has inspired a continuously evolving interdisciplinary field of theoretical debate, as well as extensive empirical research examining the regulatory processes, mechanisms and organisations that influence environmental management and outcomes at global, regional and domestic levels. ${ }^{17}$ The distinction between government and governance, the shift to 'new' policy instruments and the need for collaboration between private, public and non-governmental stakeholders to achieve environmental outcomes have been prominent themes in recent environmental governance discourse. ${ }^{18}$ However, what constitutes environmental governance 'success' in a more general sense has proven more difficult to pin down. The absence of consensus on a definition of environmental governance coupled with its complex, multi-dimensional nature have exacerbated difficulties in establishing an accepted evaluative framework. ${ }^{19}$ While key features of what is considered 'good' environmental governance generally include (in various forms) 'effective collaboration, participation, deliberation, learning and new, more horizontal, forms of accountability', it is also widely acknowledged that these criteria are, in themselves, difficult to appraise. ${ }^{20}$

17 Maria Carmen Lemos and Arun Agrawal, 'Environmental Governance' (2006) 31 Annual Review of Environmental Resources 297-325, 298.

18 Cameron Holley, Neil Gunningham and Clifford Shearing, The New Environmental Governance (Routledge 2013); Andrew Jordan, Rüdiger K W Wurzel and Anthony R Zito, 'New Instruments of Environmental Governance: Patterns and Pathways of Change' (2003) 12(1) Environmental Politics 1-24; Philipp Pattberg and Fariborz Zelli (eds), Environmental Politics and Governance in the Anthropocene: Institutions and Legitimacy in a Complex World (Routledge 2016); Marleen Buizer, Bas Arts and Kasper Kok, 'Governance, Scale and the Environment: The Importance of Recognizing Knowledge Claims in Transdisciplinary Arenas' (2011) 16(1) Ecology and Society 21; Magali A Delmas and Oran R Young, Governance for the Environment: New Perspectives (Cambridge University Press 2009).

19 John Vogler and Andrew Jordan. 'Governance and the Environment' in Frans Berkhout, Negotiating Environmental Change: New Perspectives from Social Science (Edward Elgar 2003) 137-58.

20 Holley et al (n 18) 12. 
Although there are inherent difficulties in developing a framework that can evaluate the success of a concept as expansive as environmental governance, the integration of environmental concerns across policy areas is widely perceived as central to achieving effective environmental governance and sustainable development and is, in some respects, more straightforward to assess. ${ }^{21}$ Environmental policy integration (EPI) can thus be considered as one of 'the guiding axioms of green thinking and practice' and the extent to which EPI has occurred can provide insights into wider environmental governance considerations. $^{22}$ On one level, the concept is an important policy-making principle, but it has been argued that the enhanced legal grounding bestowed upon EPI in some contexts (e.g. within the EU) has elevated its status to a quasi-constitutional 'standard to be observed'.23 As a result, academics and policy-makers have sought to develop systematic analytical frameworks that can shed light on the extent to which EPI has occurred in a given context. ${ }^{24}$ One of the most comprehensive of these has been created by the European Environment Agency (EEA). The features identified within the EEA framework include political commitment and strategic vision; administrative culture and practices enabling environmental co-operation, coordination and transparency; environmental integration into policies and programmes; availability of environmental information; mechanisms for engagement in consultation and participation; effective use of policy instruments; monitoring and learning from experience; mechanisms for environmental policy evaluation; state of the environment reporting; and appropriate and coherent use of environmental indicators and feed-back mechanisms. ${ }^{25}$ By considering how these features operate in a specific context, insights into the overall level of EPI can thus demonstrate strengths and weaknesses in systems of environmental governance.

In Northern Ireland scrutiny reports published over the last three decades have highlighted significant problems with how the environment is managed and protected. ${ }^{26}$ There have also been reviews that have explicitly sought to demonstrate environmental governance failures and which have highlighted directions for reform. ${ }^{27}$ These scrutiny reports and reviews have been analysed in detail elsewhere. ${ }^{28}$ This article will focus on three dominant themes that have characterised critiques of environmental governance in this jurisdiction: problematic environmental regulatory structures; outdated or ineffective

21 Hens Runhaar, Peter Driessen and Caroline Uittenbroek, 'Towards a Systematic Framework for the Analysis of Environmental Policy Integration' (2014) 24(4) Environmental Policy and Governance 233-46; Gerard Mullally and Niall P Dunphy, State of Play Review of Environmental Policy Integration Literature (Research Series Paper 7, National Economic and Social Development Office 2015) <http://files.nesc.ie/ nesc_research_series/Research_Series_Paper_7_UCC.pdf $>$.

22 Andrew Jordan and Andrea Lenschow, 'Environmental Policy Integration: A State of the Art Review' (2010) 20(3) Environmental Policy and Governance 147-58, 156.

23 Ibid 148. Under Article 6 of the European Community Treaty, 'environmental protection requirements must be integrated into the definition and implementation of the Community policies and activities ... in particular with a view to promoting sustainable development'.

24 William Lafferty and Eivind Hovden, 'Environmental Policy Integration: Towards an Analytical Framework' (2003) 12(3) Environmental Politics 1-22; Måns Nilsson and Åsa Persson, 'Framework for Analysing Environmental Policy Integration' (2003) 5(4) Journal of Environmental Policy and Planning 333-59.

25 EEA, Environmental Policy Integration in Europe: State of Play and an Evaluative Framework (Technical Report 2/2005, EEA 2005) <www.ieep.eu/work-areas/environmental-governance/environmental-policyintegration $/>50-5$.

26 NIAO (n 5); NIAC (n 6); PAC (n 7); CJI 2007, CJI 2011 and CJI 2015 (n 8).

27 Macrory (n 9) and Burke et al (n 9).

28 Ciara Brennan, The Enforcement of Environmental Regulation in Northern Ireland: A Story of Politics, Penalties and Paradigm Shifts? (PhD thesis, Queen's University Belfast 2013); Turner 2006a, 2006b and 2009 (n 11); Turner and Brennan (n 10); Brennan (n 2). 
environmental law and policy; and unsatisfactory delivery of environmental regulation in practice. These themes are not mutually exclusive, nor are they the only problems to have been identified. However, they do represent the most recurrent 'headline' issues raised in the Northern Irish context and also broadly mirror the key policy levels considered within other recent environmental governance research. ${ }^{29}$ Examining these issues through the lens of the EEA's EPI framework at a time of significant political turmoil will assist in clarifying features of Northern Ireland's existing environmental governance arrangements that are in particular need of reform and highlight pathways towards delivering these reforms in practice.

\section{A history of environmental governance dysfunction}

\subsection{Political MANOEUVRING, POWER-SHARING AND STRUCTURES OF ENVIRONMENTAL GOVERNANCE}

The structural arrangements for the delivery of environmental regulation in Northern Ireland remain enigmatic within the UK and Ireland and are perceived with deep dissatisfaction by ENGOs, academics, almost all of Northern Ireland's political parties and public scrutiny bodies. ${ }^{30}$ The most obvious difference (and one around which environmental governance debates have coalesced) is the lack of an 'independent' environmental protection agency (IEPA), where environmental regulation is delivered by a body at arms-length from central government. ${ }^{31}$ The rationale for this separation (which exists in all other parts of the UK and Ireland) is essentially to prevent political interference in regulatory decision-making, but also to create a body that can act as a champion for environmental interests and whose decision-making is guided by the need to protect the environment rather than any other factors. ${ }^{32}$ However, uniquely within the UK, the NIEA carries out the bulk of regulatory activities relating to the environment as an executive agency within a central government department. ${ }^{33}$ Although the presence of an IEPA is not necessarily a prerequisite for effective environmental protection, many of the regulatory failures that have occurred over the past 30 years have been attributed to this feature of Northern Ireland's environmental governance arrangements. ${ }^{34}$ Particularly problematic issues have been the creation of 'poacher-gamekeeper' scenarios within environmental regulation, ${ }^{35}$ allegations of political interference in regulatory decisionmaking ${ }^{36}$ and inconsistent environmental policy-making dependant on the political

29 Wurzel, Zito and Jordan, for example, adopt an institutionalist approach which examines organisational structures, policy style and policy goals/strategies in Austria, Germany, the Netherlands and the UK and how these factors have influenced and are influenced by environmental policy instruments: Rüdiger K W Wurzel, Anthony R Zito and Andrew J Jordan, Environmental Governance in Europe: A Comparative Analysis of the Use of New Environmental Policy Instruments (Edward Elgar 2013) 47.

30 Turner and Brennan ( $\mathrm{n} 10$ ).

31 Typically, in the form of a non-departmental public body (NDPB).

32 Burke et al (n 9) 50-3.

33 Ibid 50.

34 Ibid.

35 For example, one highly criticised arrangement meant that district councils in Northern Ireland held responsibility for both operational and regulatory functions associated with waste management until 2004. This was identified as very problematic as far back as 1990 by a report of the House of Commons Select Committee (n 4).

36 This problem has been raised by the CJI on a number of occasions: CJI 2007, CJI 2011 and CJI 2015 (n 8). 
allegiance of successive environment ministers. ${ }^{37}$ The recent reorganisation of government departments has also arguably enhanced the risk of agency-capture by increasing the proximity between the regulator and the regulated community within the new Department of Agriculture, Environment and Rural Affairs (DAERA). ${ }^{38}$

Resistance to any change to the current arrangements and particularly to the externalisation of environmental regulation in Northern Ireland has been persistent and is demonstrative of the gross politicisation of environmental issues in this jurisdiction. Historically, maintaining a viable workload for the old Department of the Environment (DOE) arguably required the presence of the NIEA, which represented a large part of its daily business. ${ }^{39}$ This consideration was particularly relevant in the mid-2000s, when removal of the NIEA would have essentially forced the very unstable power-sharing Executive to undertake a review of how executive responsibilities were divided across government departments. ${ }^{40}$ Until recently therefore, it could be argued that preserving the NIEA within the DOE was essential to maintaining the correct number of government departments in support of power-sharing arrangements. Given the constitutional and political balancing act that surrounded the make-up of various departments and the need to 'spread out' responsibilities for key government functions across departmental and political divides, this was undoubtedly one of the primary (although not officially acknowledged) reasons for maintaining the status quo for many years. ${ }^{41}$ However, although this particular driver for a centralised environmental regulator was removed after departmental reshuffles in 2016 when the NIEA was subsumed within the new DAERA, political resistance to externalisation of the regulatory function has nevertheless been retained. 42

The explanations for this tenacious resistance to independent environmental regulation are varied. However, it is worth noting that all political parties (and direct rule ministers) have indicated support for an IEPA at some point within the last decade except for the Democratic Unionist Party (DUP) which has persistently halted debates around the issue in the face of both political opposition and overwhelming public

37 Turner and Brennan (n 10). Recent examples throw this issue into sharp resolution. With the transfer of the NIEA to the new DAERA, concerns surrounding the ability of the NIEA to effectively regulate agricultural pollution have been rife. The SDLP Minister for the Environment, Mark Durkan, halted negotiations surrounding a Memorandum of Understanding (MOU) between the NIEA and the Ulster Farmers Union (UFU) due to concerns that it would force the NIEA to treat agricultural polluters with more leniency than other industries. This decision was supported by ENGOS, but was simply reversed when the DUP Minister Michelle McIlveen took over the running of the Department in May 2016. See 'Ulster Farmers Union Seeking to Reverse SDLP Minister's Veto on Agricultural Pollution Plan' Irish News (Belfast, 30 May 2016) <www.irishnews.com/news/2016/05/30/news/ulster-farmers-union-seeking-to-reverse-sdlp-minister-sveto-on-agricultural-pollution-plan-537872/>.

38 Turner and Brennan (n 10). The political influence that major industry or other stakeholders (e.g. the agricultural community) hold over regulators and rule-makers, as well as common interests between the regulated community and the regulator, have been identified as key triggers for agency-capture. See Philip Lowe, Judy Clark, Susanne Seymour and Neil Ward, Moralizing the Environment: Countryside Change, Farming and Pollution (UCL Press 1997). This risk has clearly been exacerbated by the merging of DARD and the DOE and the continued location of the NIEA within this new department.

39 Turner and Brennan (n 10) 523.

40 Ibid. In 2008, when Arlene Foster (who was at that time the DUP Minister for the Environment) rejected the need for an IEPA, devolution had only been recently restored after its collapse between 2002-2007.

41 Ibid.

42 Minister for Agriculture, the Environment and Rural Affairs, Michelle McIlveen, stated in September 2016 that she had no intention of establishing an IEPA. 'Oral Answers to Questions - Agriculture, Environment and Rural Affairs' in the Northern Ireland Assembly at 3:15 pm on 20 September 2016 $<$ www.theyworkforyou.com/ni/?id=2016-10-25.3.76>. 
support. ${ }^{43}$ With DUP ministers holding the environmental portfolio intermittently over the last decade, ${ }^{44}$ any consultative exercises examining the issue of an IEPA carried out by environment ministers from other parties (notably the Social Democratic and Labour Party's (SDLP) Alex Attwood ${ }^{45}$ and Mark H Durkan) ${ }^{46}$ have simply been discontinued once the ministerial portfolio has changed hands to the DUP. In the face of such forceful rebuttal from Northern Ireland's largest political party, ${ }^{47}$ the frustration of attempts to establish an IEPA has thus far been successful. It has been suggested that the reasons for the DUP's pronounced antipathy towards the establishment of an IEPA relate to its aggressive focus on economic development (which it presumably believes would be stymied by interference from an environmental regulator) and the party's need to appease sections of its electorate that might benefit from 'light-touch' regulation. ${ }^{48}$ The party itself has in the past stated that it 'take[s] the environment too seriously' to externalise regulation. However, given the tidal wave of criticism that has engulfed the performance of the environmental regulator in recent history (not to mention the RHI scandal), this particular assertion seems increasingly difficult to justify. ${ }^{49}$

\subsection{A SHORT-SIGHTED AND FRAGMENTED APPROACH TO ENVIRONMENTAL LAW AND POLICY-MAKING}

Another recurring theme in critiques of Northern Ireland's environmental governance relates to numerous policy decisions made by the devolved government that have had, or have the potential to have, a negative environmental impact. The resistance to making political commitments relating to climate change, ${ }^{50}$ ineffective policy-making surrounding

43 Turner and Brennan (n 10) 517.

44 At the time of writing (early June 2017) there was no DAERA Minister in place as the Stormont institutions had not yet been established following their collapse in January 2017. Prior to the collapse of the devolved assembly, the Minister for Agriculture, Environment and Rural Affairs was Michelle McIlveen (DUP) who took ministerial responsibility for the newly formed DAERA in May 2016. Before the formation of DAERA in May 2016, Mark H Durkan (SDLP) was the Minister for the Environment for the DOE. Durkan was preceded by Alex Attwood (SDLP) who held the office from May 2011 until July 2013. When devolution was restored in 2007, the DUP held the environment portfolio until May 2011 when the SDLP took over. DUP Environment Ministers during this period were Edwin Poots (July 2009-May 2011), Sammy Wilson (June 2008-June 2009) and Arlene Foster (May 2007-June 2008).

45 DOE, Environmental Governance in Northern Ireland: A Discussion Document (DOE 2011).

46 DOE, Environmental Governance in Northern Ireland: Discussion Document (DOE 2015) <www.daerani.gov.uk/sites/default/files/consultations/doe/environmental-governance-paper.pdf>.

47 While the DUP remains Northern Ireland's biggest political party in terms of first preference votes, Sinn Féin's strong performance in the most recent election (March 2017) means that there is now only one assembly seat between the two parties. Henry McDonald and Jamie Grierson, 'Sinn Féin Makes Major Gains in Northern Ireland Elections' The Guardian (London, 4 March 2017) <www.theguardian.com/politics/2017/mar/03/dup-and-sinn-fein-on-course-to-dominate-northern-irelandassembly>.

48 The DUP has persistently sought relaxation of agricultural regulation, see Turner and Brennan (n 10) 521; Brennan (n 2) 495. Most recently, establishing a highly criticised MOU with the UFU (n 37).

49 Ministerial Statement on Environmental Governance, Minutes of the Northern Ireland Assembly (27 May 2008) <http://archive.niassembly.gov.uk/record/reports2007/080527.htm>.

50 Sharon Turner, 'Northern Ireland's Consent to the Climate Change Act 2008: Symbol or Illusion?’ (2013) 25(1) Journal of Environmental Law 63-93; Sharon Turner, 'Committing to Effective Climate Governance in Northern Ireland: A Defining Test of Devolution' (2013) 25(2) Journal of Environmental Law 203-34; Thomas Muinzer, 'Warming Up: Northern Ireland's Developing Response to Climate Change in the Context of UK Devolution' (September/October 2016) 96 UKELA E-Law 19. 
mineral abstraction, ${ }^{51}$ policies that have failed to protect important natural resources, ${ }^{52}$ policy proposals with the potential to erode public participation in environmental decision-making ${ }^{53}$ and planning decisions that have resulted in damage to important natural (and cultural) heritage sites ${ }^{54}$ have all been well documented. In addition, although Northern Ireland has an abundance of environmental policies and strategies, there is a lack of any overarching strategic policy or vision of the environment in this jurisdiction and policy (like arrangements for enforcement) is produced in a siloed and fragmented way. ${ }^{55}$ This has contributed to a confusing, and sometimes conflicting, policy framework in areas such as transport, environment, land-use planning, education and social

51 A litany of concerns has surrounded the process whereby planning permission was granted to Dalradian for an exploratory gold mine near Gortin, Co Tyrone. Connla Young, 'Tyrone Residents Voice Fears over Cyanide Goldmine Plan' Irish News (Belfast, 5 February 2016) <www.irishnews.com/news/2016/02/05/news/tyroneresidents-voice-fears-over-cyanide-gold-mine-plan-407011/ $>$ and for detail on the alleged procedural irregularities <https://www.foe.co.uk/sites/default/files/downloads/10-concerns-about-dalradian-goldmine-75430.pdf>.

52 For example, government support of the controversial exploratory drilling for oil at a site near Woodburn Forest near Carrickfergus in 2016 attracted criticism from environmental activists across Ireland, who feared water pollution and the release of contaminants. Ultimately, no exploitable oil was discovered. However, the DUP's Sammy Wilson (a previous Northern Ireland Environment Minister) said of the explorations: 'I hope they find as much oil in Carrickfergus as there is in Texas. If it becomes the centre of the oil industry in the UK I will be over the moon in terms of investment for the area, jobs for the area, the potential for spin-off industry. It will be like Christmas come early.' Gerry Moriarty, 'Environmental Battle as InfraStrat hunt for Antrim Oil' Irish Times (Belfast, 23 May 2016) <http://www.irishtimes.com/news/ environment/environmental-battle-as-infrastrata-hunts-for-antrim-oil-1.2656902>.

53 For example, in 2013 the Department of Justice issued a consultation on proposals to revise the costs-capping scheme for eligible environmental challenges. The Northern Ireland Environment Link (representing many of Northern Ireland's environmental NGOs) issued comments on the proposals expressing concern that they would unnecessarily (further) frustrate the ability of environmental NGOs to challenge environmental decisions via judicial review in a context where very few environmental decisions were being challenged in this way. Northern Ireland Environment Link, 'Costs Protection in Environmental Cases: Department of Justice Proposals to Revise the Costs Capping Scheme for Eligible Environmental Challenges - Comments by Northern Ireland Environment Link (February, 2016) <www.nienvironmentlink.org/cmsfiles/NIELresponse-DoJ-Costs-Protection-consultation.pdf $>$.

54 A recent example relates to the widespread campaigning targeted at the upgrading and rerouting of the A6 motorway from Belfast to Derry through the Lough Beg Wetlands which is designated as a Ramsar site, an Area of Special Scientific Interest and a Special Protected Area. In addition, the area is of cultural significance as the homeland of the renowned poet Seamus Heaney. Despite concerted campaigning by Friends of the Earth (NI) and a legal challenge brought by a private individual against the government's decision, the development looks set to go ahead - even though, at the time of writing, there is no government in place and the development is based on an environmental assessment over 10 years old. Friends of the Earth (NI) 'Disrespecting Everyday Miracles and the Living Past: The Lough Beg Wetlands and the A6 Road' (Urgent Briefing, March 2017) <www.foe.co.uk/sites/default/files/downloads/lough-beg-wetlands-a6-road103190.pdf>; Alan Erwin, 'Environmentalist Loses Challenge to Derry Dual Carriageway' Irish Times (Belfast, 28 March 2017) <www.irishtimes.com/news/crime-and-law/environmentalist-loses-challenge-to-derry-dualcarriageway-1.3028046>.

55 For example, DOE, Valuing Nature. A Biodiversity Strategy for Northern Ireland to 2020 (DOE 2015); Northern Ireland Executive, Everyone's Involved. Sustainable Development Strategy (Northern Ireland Executive 2010); DOE, Delivering Resource Efficiency: Northern Ireland Waste Management Strategy (DOE 2015); Department for Regional Development, Sustainable Water: A Long-Term Water Strategy for Northern Ireland (Department for Regional Development 2014). 
development. ${ }^{56}$ The problem is compounded by a lack of integration, cooperation and communication relating to environmental issues within the Northern Ireland Executive. ${ }^{57}$ The RHI scandal represented a classic example of this fragmented approach to environmental governance, where a deeply flawed renewable energy incentive scheme produced by one department (the Department of Enterprise Trade and Investment) was being promoted by another department (the Department of Agriculture and Rural Development (DARD)) that appeared blissfully unaware of its catastrophic economic implications. ${ }^{58}$ The DOE at the time seemed to have very little input into what was essentially an environmental scheme. However, as well as highlighting an inherently disorganised and fragmented approach, the RHI scheme in Northern Ireland also demonstrated a more fundamental cultural problem that characterises political attitudes towards the environment in this jurisdiction and seems to underpin policy decisions. While in principle the RHI scheme was designed to assist businesses in moving towards renewable energy resources, in Northern Ireland this principle was implemented with a more central focus of providing economic support to industry. ${ }^{59}$ Any environmentally beneficial aspect to the scheme was at best sidelined and at the worst reversed, so businesses could profit from funds designed to promote renewable energy - in some cases allegedly heating empty sheds to generate the profits from using more and more renewable energy resources through the scheme. ${ }^{60}$ The corruption of the 'cash for ash' RHI scheme is thus indicative of a dominant perception within Northern Ireland's political class that environmental costs are merely overheads in the business of promoting or supporting economic development and that funding schemes and policies are there to be manipulated for financial gain.

The fragmented policy landscape is also underpinned by a legislative framework that remains some years behind other parts of the UK and a legislature that has been under constant pressure to keep 'up to speed' with EU standards of environmental protection. On the one hand, important developments such as waste management licensing, an integrated system of environmental permitting and reform of environmental sanctions

56 A key example of conflicting policies relates to planning decisions and protection of nature conservation areas, see, for example, Friends of the Earth (NI) (n 54). Restructuring and reform of the planning system (involving the transfer of responsibility for preparation for Local Development Plans to local councils) and the publication of the recent Strategic Planning Policy Statement for Northern Ireland have the potential to significantly improve the strategic approach to planning: DOE, 'Strategic Planning Policy Statement for Northern Ireland' (DOE September 2015) <www.planningni.gov.uk/index/policy/ spps_28_september_2015-3.pdf>.

57 Burke et al (n 9) 42 .

58 Sean O’Driscoll and Claire O’Boyle, 'Sinn Féin's Michelle O’Neill in Firing Line over RHI as Role of her Department in Hyping Faulty Scheme Revealed' Belfast Telegraph (Belfast, 28 January 2017) <www.belfasttelegraph.co.uk/news/rhi-scandal/sinn-Féin s-michelle-oneill-in-firing-line-over-rhi-as-role-ofher-department-in-hyping-faulty-scheme-revealed-35404342.html>. The NIAO reported on the flawed scheme in July 2016 and again in June 2017, ultimately concluding that there are 'significant concerns about the operation of this scheme and the serious systemic weaknesses in controls that have facilitated the possibility of funding that is at best not in line with the spirit of the scheme and at worst is fraudulent'. Although a revised subsidy tariff introduced in 2017 has the potential to vastly reduce the annual cost of the scheme to the Northern Ireland block from $£ 30$ million per year to $f 2$ million, the new tiered rate is subject to an ongoing judicial review which has challenged the ability of the department to significantly vary the subsidy rates: NIAO, Department for the Economy Resource Accounts 2016-2017 (NIAO June 2017) <www.niauditoffice.gov.uk/sites/niao/files/media-files/CAG\%20Report\%202016-17\%20Final.pdf>.

59 Muinzer (n 1).

60 Ibid 19-20. 
have been gradually introduced, or are in the process of being introduced. ${ }^{61}$ However, these developments have occurred belatedly and there are still aspects of environmental law in Northern Ireland which require significant updating to bring them into line with other parts of the UK. ${ }^{62}$ In addition, the well-known practice of directly replicating Westminster's environmental legislation into Northern Irish environmental law with minimal local input is problematic. Although there are practical reasons for this approach given the mammoth task of transposing EU directives and the limited resources available to do so, failure to develop a context-specific legislative framework for environmental protection makes it difficult to implement and there is a risk that the actual legal thinking and understanding of the legislation will not be passed on or inform actual practice. ${ }^{63}$

On the other hand, the pivotal role that the EU has played as a driver for environmental law development in Northern Ireland has always been evident, but has been thrown into sharp resolution in the wake of the UK referendum to leave the EU. ${ }^{64}$ Although the UK as a whole would be in breach of its EU law obligations if environmental directives are not transposed and implemented in Northern Ireland, subsequent to the Northern Ireland Act 1998 the devolved government rather than Westminster is liable for the cost of any financial sanctions imposed for this failure. ${ }^{65}$ The potentially crippling financial implications of this responsibility have essentially driven environmental law reforms in subsequent years. An impressive programme of legislative modernisation in the early 2000s occurred only in response to infraction threats from the European Commission for failure to transpose environmental directives. ${ }^{66}$ Specific problems existed in relation to the Bathing Waters Directive, the Waste Framework Directive, the Integrated Pollution Prevention and Control Directive and the Drinking Water Quality Directive. ${ }^{67}$ Between 2001 and 2004, 45 separate pieces of legislation were adopted to remedy these deficiencies in direct pursuit of compliance with EU law and to

61 Criticism of Northern Ireland's failure to modernise its environmental legislation began back in 1990, when the House of Commons Select Committee on the Environment highlighted the extent of the antiquation within Northern Ireland's environmental law regimes: House of Commons Select Committee on the Environment (n 4) paras 32-3.

62 For example, the overly complex laws relating to packaging waste regulation and producer responsibility. The DAERA is currently consulting on consolidation of these rules. See, DAERA, Consultation Document on Consolidation of the Producer Responsibility Obligations (Packaging Waste) Regulations (Northern Ireland) 2007 (as amended) (2016) <www.daera-ni.gov.uk/consultations/packaging-waste-regulations-northern-ireland-2016>. Another critical issue is the absence of a properly functioning contaminated land regime. See, Brian Jack, 'Environmental Law in Northern Ireland' in Stephen McKay and Michael Murray, Planning Law and Practice in Northern Ireland (Routledge 2017) 154-5. One positive recent development is the provision for the integration of permitting systems via the Environmental Better Regulation Act (NI) 2016.

63 An example of this occurred when the rush to copy over waste legislation by DOE policy-makers in the early 2000 s in order to avoid EU infraction proceedings was entirely at odds with the ability of the Environment and Heritage Service (EHS) to effectively enforce and implement the legislation within the necessary timeframe: Brennan (n 2) 478.

64 The potential impact of Brexit on environmental governance in Northern Ireland more generally will be discussed in more detail in section 5.

65 As a function of the MOU and supplementary agreements relating to devolution, Northern Ireland is liable for payment of any infraction fines imposed by the European Commission on the UK for failure to implement European directives that fall within the responsibility of the Northern Ireland Assembly: Office of the Deputy Prime Minister, Memorandum of Understanding and Supplementary Agreements: between the United Kingdom Government, Scottish Ministers and the Cabinet of the National Assembly for Wales and the Northern Ireland Executive Committee (Cm 5420, 2001) para B4.25.

66 Turner 2006a (n 11).

67 Jack (n 62) 155. 
avoid infraction proceedings and subsequent fines. ${ }^{68}$ Since this unprecedented period of legislative modernisation, the spectre of EU infraction fines has continued to exert pressure on Northern Ireland's environmental legislators to update water, air, pollution prevention and control and biodiversity regimes - albeit slowly and imperfectly. ${ }^{69}$ While concern about the risk of post-Brexit dilution of environmental standards has been expressed across the UK (and will be addressed in more detail below), the EU's role as the primary motivating force behind any form of legislative modernisation in Northern Ireland arguably elevates the chances of its environmental law and policy framework stagnating, or even decaying in a post-Brexit scenario.

\subsection{CATASTROPHIC REGULATORY AND ENFORCEMENT FAILURES}

Possibly the most persistent theme that has dominated discussions surrounding environmental governance in Northern Ireland is the real and perceived failure to implement environmental regulation in practice and the resistance, or lethargy, with which government has responded to reports that have criticised its performance. This demonstrates not only antipathy towards environmental protection, but also blatant disregard for the scrutiny bodies established to audit and monitor regulatory performance. $^{70}$ The problematic approach to regulation does not relate to any one distinct category of environmental harm but is endemic and indicative of a systemic failure to regulate environmentally harmful activities. While recent commentary has focused on the particularly visible issue of waste management, ${ }^{71}$ critiques of regulation span all areas of the environment including illegal quarrying and mineral extraction, planning, ${ }^{72}$ water pollution from agriculture and sewage, and the protection of designated conservation sites. ${ }^{73}$ Although the entire process of regulation has been problematic, one of the most criticised functions of the NIEA has been its approach to enforcement of environmental law, almost all aspects of which have been the subject of intense condemnation. ${ }^{74}$ Key issues relate to the NIEA's enforcement policy, its fragmented internal structure, the lack of an internal legal team, problems with prosecution of environmental crime by both the NIEA and the Public Prosecution Service (PPS) and the

68 Turner 2006a (n 11) 65.

69 Jack (n 62) 155.

70 For example, in relation to water pollution, the NIAO report published in 1998 (n 5) criticised DOE for failing to respond to the Halcrow Report (William Halcrow, Efficiency Study of the Environmental Protection Division of the Department of the Environment (NI) (Department of the Environment 1989) and the PAC report published in 2000 (n 7) similarly criticised the department for failing to respond to the NIAO recommendations. In 1990 Milton (K Milton, Our Countryside, Our Concern: Policy and Practice of Conservation in Northern Ireland (Northern Ireland Environment Link 1990)) reported only a 'partial' implementation of the previous Balfour recommendations (J Balfour, A New Look at the Northern Ireland Countryside (HMSO 1984) relating to nature conservation in 1984). In 2006 the PAC (House of Commons Committee of Public Accounts, Northern Ireland's Waste Management Strategy (HC 2005-06, 741)) criticised the DOE for failure to respond to the recommendations of the WMAB in 2004 (Waste Management Advisory Board for Northern Ireland, Waste Management Strategy Review Report (EHS 2004)). In 2007, CJI (n 8) criticised the DOE generally for its failure to respond to previous criticisms.

71 Brennan (n 2); CJI 2015 (n 8); and Mills (n 12).

72 Planning functions were transferred to local councils in 2015. For analysis of this process, see Stephen McKay and Michael Murray, Planning Law and Practice in Northern Ireland (Routledge 2017). Enforcement of planning law has historically been highly problematic, e.g. Stephen McKay and Michael Murray, 'In Pursuit of Regulatory Compliance: A Study of Planning Enforcement Structures in Northern Ireland' (2014) 85(3) Town Planning Review 387-410.

73 For a detailed analysis of reports into the problems with environmental regulation across these areas, see Brennan (n 28) 19-50.

74 Ibid. 
sentences imposed in environmental prosecutions. ${ }^{75}$ Despite significant effort from regulatory staff working within the NIEA, current regulatory arrangements are notably falling behind those in neighbouring countries.

The enforcement policy of the NIEA is not sufficiently detailed to provide a transparent account of the agency's overall approach. ${ }^{76}$ While the policy has been reformed in recent years, it remains a short and undetailed document which contrasts significantly with the comprehensive policy and guidance documents produced by, for example, the English Environment Agency (EA). ${ }^{77}$ This has the potential to create uncertainty about the NIEA's approach to enforcement both within the agency itself and within the regulated community. This uncertainty is exacerbated by the lack of any centralised enforcement unit within the NIEA, where enforcement is fragmented across the whole organisation leading to a disparate and inconsistent approach and gaps in the enforcement response. ${ }^{78}$ The implications of this fragmented approach were thrown into sharp resolution with the discovery of the massive illegal dump at Mobuoy in County Derry in 2014. The 'superdump', now recognised as one of the biggest illegal dump sites in Europe, was created by environmental criminals masquerading behind the front of a legitimate, licensed recycling company. ${ }^{79}$ It has since emerged that one of the most significant problems with the regulation of the site in question was that there were essentially multiple parts of the NIEA (and local councils) with responsibility for discrete categories of environmental regulation dealing with different aspects of the operation. ${ }^{80}$ Within the NIEA, the Environmental Crime Unit (ECU) eventually began dealing with the 'serious' crime aspect of the offending when its scale became clear in 2012.81 The Land and Resource Management Unit issued the operators of the site with a licence and were (supposed to be) regulating the licensed activities for years before the illegal dumping was discovered. ${ }^{82}$ The Water Management Unit had responded to reports of water pollution in the nearby River Faughan ${ }^{83}$ and because there are designated protected sites nearby the Conservation, Designation and Protection team also had responsibilities to ensure those sites were not harmed. ${ }^{84}$ In addition to these multiple NIEA teams, the local council had also responded to issues relating to pest control and nuisance odours emitting from the site. ${ }^{85}$ The complex regulation of the site and a lack of an integrated approach or communication between the various teams dealing with the operations at Mobuoy essentially created a scenario where the serious offending slipped through the cracks between the remits of the numerous bodies involved. ${ }^{86}$ This issue has been exacerbated in the context of waste regulation due to the lack of a comprehensive

75 Ibid.

76 NIEA, Enforcement Policy (NIEA 2011) <www.daera-ni.gov.uk/sites/default/files/publications/doe/nieaenforcement-document-2011.pdf $>$.

77 The EA's enforcement policy documents are available at <www.gov.uk/government/publications/ environment-agency-enforcement-and-sanctions-statement>.

78 CJI 2007 (n 8) 5, para 2.3.

79 Brennan (n 2).

80 Mills (n 12).

81 Ibid 13.

82 Ibid 11-12.

83 Ibid 12.

84 Ibid 14.

85 Ibid.

86 Brennan (n 2) 482. 
protocol between the NIEA and local government establishing a clear delineation of responsibilities for dealing with illegal disposal of waste. ${ }^{87}$

Another recurrent issue is that the NIEA does not have its own legal team, and the lack of any in-house lawyers means that potential prosecutions are referred to the PPS and handled by PPS staff alongside all other departmental business. ${ }^{88}$ This practice is notably out of step with what takes place in the EA in England, Natural Resources Wales (NRW) and in the Scottish Environmental Protection Agency (SEPA). ${ }^{89}$ While the arrangement offers flexibility in the type of advice that can be provided by PPS staff, general departmental lawyers will not have as much knowledge and experience as someone specialising in one particular area and this could generate a potential imbalance in legal specialism and a higher rate of case 'failure'. 90 In addition, the lack of a legal core in DAERA means that the legal grounding for the business of regulation is not sufficiently embedded into the culture of the department and the importance of the NIEA's enforcement function is minimised. This is clearly demonstrated by the fact that, while the NIEA's strategic priorities include reference to environmental crime, none of the strategic goals refer explicitly to this core aspect of the NIEA's role ${ }^{91}$ and assessments of the NIEA's internal culture reflect an organisation heavily science-focused where enforcement is perceived as a secondary function. ${ }^{92}$ The CJI in particular has highlighted the need within the NIEA for 'a stronger emphasis on upholding the law and removing any ambiguity as to the management of breaches of the law'. ${ }^{93}$ It has also criticised how environmental enforcement has been undertaken in respect of discretion, consistency and rigour. The CJI has made numerous suggestions in this regard (across several reports) that could improve the status quo, such as strategic changes, oversight systems and better training.

The approach to, and 'success' of, prosecutions for breaches of environmental law have also been the subject of significant debate. This relates not only to a perception that the NIEA does not always prosecute when it should and instead targets 'low-hanging fruit' or easy wins, but also that the handling of environmental prosecutions once they enter the criminal justice system is highly problematic. ${ }^{94}$ Although substantial penalties have been provided for within environmental legislation, in general, sentences imposed by the courts fall far below the maximum penalties, below any threshold that could create a deterrent to further commission of environmental crime and far below the levels of penalties imposed in other parts of the UK. ${ }^{95}$ While sentencing guidelines were

87 Formal 'fly-tipping' protocols exist elsewhere in the UK to deal with this problem. For the fly-tipping protocol in England and Wales, see England and Wales Environment Agency and Local Government Association/Welsh Local Government Association, Fly-tipping and Illegal Waste Activities Working Better Together Protocol Series: Protocol 6 <http://www.flytippingactionwales.org/files/8113/5877/5049/flytipping_protocol.pdf $>$. For the Scottish protocol, see Scottish Flytipping Forum, 'Fly-tipping in Scotland: A Guide to Prevention and Enforcement' (December 2010) <http://dumbdumpers.org/wpcontent/uploads/2014/07/Flytipping-in-Scotland-A-Guide-to-Prevention-and-Enforcement.pdf $>34$.

88 NIEA (n 58) 5.

89 Brennan (n 28) 201-7.

90 The CJI found that on average around $25 \%$ of cases referred to the PPS by the NIEA's Environmental Crime Unit failed the test for prosecution: CJI (2015) (n 8) 34.

91 Ibid. In 2015, the CJI concluded that: 'A key strategic document for the NIEA is its Strategic Priorities for 2012-22. The document states that "When standards are breached or crime detected we investigate and pursue offenders vigorously."”

92 Ibid 6.

93 Ibid.

94 Brennan (n 28) 197-276.

95 Ibid and CJI 2007 (n 8). 
eventually produced in Northern Ireland in 2012, it remains unclear as to whether these guidelines have had any meaningful impact on the levels of fines imposed. ${ }^{96}$ Northern Ireland is also well behind the rest of the UK in its ability to have an effective programme of environmental sanctions. Penalties for breaches of environmental legislation in Northern Ireland are currently nearly always applied through the criminal justice system, whereas other jurisdictions have been expanding the applicability of a wider range of sanctions (e.g. enforcement undertakings), from some discrete sectors like packaging, into new environmental regimes. ${ }^{97}$ A commitment from (the then DUP Environment Minister) Arlene Foster in 2008 to deliver a new sanctioning regime as part of her programme of regulatory reform has yet to come to fruition. ${ }^{98}$

\section{The impact and implications of weak environmental governance}

Significant dysfunction and regulatory failure have clearly characterised Northern Ireland's environmental governance experience to date and it is clear that almost all of the features highlighted in the EPI framework are either entirely absent or seriously compromised. There is a clear lack of political commitment and strategic vision in terms of environmental protection. This has been demonstrated at all policy levels, from the failure to externalise regulation and remove the risk of political interference at a structural level, to weak environmental policy-making where economic development has unapologetically trumped environmental protection and an absence of political will to enhance environmental regulation has been displayed even in the face of catastrophic failures. There is a highly fragmented approach to environmental governance at Executive level as well as within the NIEA. This demonstrates a profound lack of policy integration and is representative of an administrative culture and set of practices that fail to enable co-operation between actors involved in environmental protection, facilitate coordination of plans and strategies and deliver environmental decision-making in a transparent way. The superficial degree of environmental policy integration also displays little concern for the long-term impacts of weak environmental governance or sustainable development. There has been a significant lack of innovation in terms of using policy instrument design and application in a context-specific way, with an over-reliance on replicating developments in other parts of the UK in spite of distinctive regional challenges (e.g. cross-border waste crime). Although monitoring and publication of state-of-theenvironment reporting occurs, a key issue has been government's failure to respond to either indicators of environmental degradation or to criticism of government policy and practice by the scrutiny community. The divergence from what can be considered 'good' environmental governance is clear and the environmental, economic and socio-political consequences of these failures cannot now be overestimated.

Recently published figures portray a stark, and in many cases declining, assessment of the state of Northern Ireland's environmental and natural resources. As of 2015, only 33 per cent of Northern Ireland's rivers, 24 per cent of its lakes and 36 per cent of marine waterbodies met the Water Framework Directive targets of good ecological status. ${ }^{99}$

96 Available at <www.jsbni.com/Publications/sentencing-guides-magistrates-court/Pages/EnvironmentOffences.aspx>. In July 2017 a County Tyrone farmer was fined only $£, 500$ for the illegal disposal of over 2000 tonnes of waste in an area of birch bog on his land. 'Tyrone man fined f,500 over tonnes of illegal waste' BBC News (BBC, 10 July 2017) < http://www.bbc.co.uk/news/uk-northern-ireland-40558040>.

97 Introduced by the Regulatory Enforcement and Sanctions Act 2008 in England and Wales and Environmental Regulation (Enforcement Measures) (Scotland) Order 2015 in Scotland.

98 Ministerial Statement (n 56) 3-4.

99 DAERA, Northern Ireland Environmental Statistics Report March 2016 <www.daerani.gov.uk/sites/default/files/publications/doe/ni-environmental-statistics-report-2016.pdf> 40, 54 . 
DAERA also reported in 2015 that the total number of reported water pollution incidents had increased by 6 per cent compared with the last reported year and the number of substantiated incidents had increased by 11 per cent compared with $2012 .{ }^{100}$ In addition to poor water quality in rivers, lakes and marine water bodies, Northern Ireland's natural heritage sites and wildlife also appear to be at significant risk. In relation to natural heritage, 33 per cent of features in protected areas were deemed as being in unfavourable condition in 2016, compared to 30 per cent in 2015. ${ }^{101}$ Between 1994/95 and 2013/14, the total wetland bird population of Northern Ireland is estimated to have decreased by 26 per cent with coastal populations declining by 16 per cent and freshwater populations by 41 per cent. ${ }^{102}$ Significant concern surrounds the maintenance of Northern Ireland's biodiversity, the health of which has been ranked lowest within the UK. ${ }^{103}$ Pollution of the terrestrial environment is also endemic and one of the most significant environmental problems in Northern Ireland relates to the illegal disposal of waste. There are hundreds of illegal dump sites in Northern Ireland containing millions of tonnes of waste (some of which might potentially leach into watercourses and drinking water in the future). ${ }^{104}$ More than a million cubic metres of waste is estimated to be buried at the Mobuoy 'superdump' alone. ${ }^{105}$ There does not appear to be an adequate and visibly resourced national remediation plan to deal with these sites, nor is there a fully functioning contaminated land regime to deal with historic pollution. The cumulative impact of these problems means that Northern Ireland's environment can now be considered to be an environment in crisis. However, given that evidence of serious environmental degradation has thus far been ineffective in persuading Northern Ireland's government to undertake meaningful reform, it is unlikely that environmental factors alone will sway politicians towards addressing these problems.

100 Ibid 49. Agriculture accounts for the highest proportion of water pollution incidents (26.9\%), followed by industry and other (18.5\% each), domestic (18.3\%) and Northern Ireland Water Ltd (16.3\%). Significant controversy surrounds the level of penalties imposed by the courts on Northern Ireland's single most prolific polluter Northern Ireland Water (which was prosecuted 41 times between 2011 and 2016) and also surrounding the regulation of agricultural pollution incidents: "Repeat Offender" Northern Ireland Water Pays Out f80k on Pollution Fines in Five Years' Belfast Telegraph (Belfast, 25 November 2016). $<$ www.belfasttelegraph.co.uk/news/environment/repeat-offender-northern-ireland-water-pays-out-80k-onpollution-fines-in-five-years-35243453.html>; Suzie Cave and Des McKibbon, River Pollution in Northern Ireland: An Overview of Causes and Monitoring Systems, with Examples of Preventative Measures (Northern Ireland Assembly Research Paper NIAR 691-15 2016) <www.niassembly.gov.uk/ globalassets/documents/raise/publications/2016/environment/2016.pdf>; Conor Macauley, 'Farmers Union Wins Pollution Appeal' BBC News (7 February 2017) <www.bbc.co.uk/news/uk-northern-ireland38895343>; Linda Stewart, 'Fury at Deal to Let Farmers Escape Fines for Pollution' Belfast Telegraph (Belfast, 6 April 2015) <www.belfasttelegraph.co.uk/news/environment/fury-at-deal-to-let-farmers-escape-fines-forpollution-31119738.html>.

101 DAERA, Northern Ireland Environmental Statistics Report March 2017 <www.daerani.gov.uk/sites/default/files/publications/daera/ni-environmental-statistics-report-2017_2.PDF> 69.

102 Ibid 73. The report notes that there is significant variability in the usage of different sites by wild bird populations and shifts in population may be in some cases attributable to wider climatic change.

103 The Biodiversity Intactness Index (BII) is one measure used to assess the extent of the loss of nature due to human activities going back centuries. BII values below $90 \%$ indicate that ecosystems may have fallen below the point at which they can reliably meet society's needs. The value for Northern Ireland is $80 \%$. Of the 218 countries for which BII values have been calculated, Northern Ireland is ranked 24th from the bottom and is ranked the lowest of the UK's four countries. State of Nature, State of Nature Report 2016: Northern Ireland <www.bto.org/sites/default/files/publications/state-of-nature-report-2016-northern-ireland.pdf> 3.

104 Cormac Campbell, 'Waking up to Waste: How Northern Ireland's Waste Problem Could Leave a Toxic Legacy' The Detail (Belfast , 7 November 2016) <www.thedetail.tv/articles/waking-up-to-waste-how-northern-irelands-waste-problem-could-leave-a-toxic-legacy>.

105 Details on the Mobuoy dump and documents relating to the site can be found at <https://www.daerani.gov.uk/articles/mobuoy-road-waste-project $>$. 
Perhaps the consequences of environmental governance failings that provide the most political mileage for change relate to the economic costs stemming from either direct clean-up expenses associated with pollution, mitigation of harmful pollutants already emitted and, less tangibly, the value of lost benefits that could have been derived from good environmental governance. Conservative estimates suggest that resolution of the RHI commitments alone could cost the Northern Ireland taxpayer f,490 million (never mind the $f_{600}$ million that the rest of the UK must 'chip in'). ${ }^{106} \mathrm{~A}$ high price to pay for at best inept application and at worst alleged political corruption of a policy designed to promote sustainable energy use. Although difficult to estimate because of ongoing investigations, some repatriation costs being paid by the Republic of Ireland for cross-border waste ${ }^{107}$ and several remediation options, the clean-up costs resulting from illegal dumping have the potential to reach the eye-watering figure of $£ 440$ million. This is comprised of an estimated $\mathcal{f}_{140}$ million to clean up the superdump at Mobuoy Road in Derry, $£ 250$ million to clean up previously discovered illegal dump sites and an estimated $f, 50$ million to remediate sites currently being investigated. ${ }^{108}$ Cleaning up the toxic by-products of illegal fuel laundering has also cost the Northern Ireland government $£, 960,321$ between 2012 and 2015. ${ }^{109}$ A further $£ 28,791$ was spent dealing with problems caused to the water system by toxic sludge linked to fuel smuggling. ${ }^{110}$ Although data relating to the cost of remediation of damage to protected sites is unavailable, $f 1$ million has already been spent on developing a remediation restoration plan after damage was caused to Strangford Lough and the Northern Ireland government was threatened with infraction proceedings for non-compliance with the Habitats Directive. ${ }^{111}$ Combining the cost of RHI, cleaning up illegal dumping and fuel laundering gives a total and already incurred cost of over $f 1$ billion.

Loss of tax revenue can also be considered a direct consequence of weak enforcement of environmental law. It has been estimated that illegal fuel laundering alone between 2009 and 2014 resulted in a loss of around $£, 400$ million in lost revenue. ${ }^{112}$ For illegal waste

106 Muinzer (n 1) and Conor Macauley, 'RHI Firms: Minister Using Us as a Political Football' BBC News (22 February 2017) <www.bbc.co.uk/news/uk-northern-ireland-39052217>.

107 Olivia Kelly, 'Over 10,000 Tonnes of Waste to Be Repatriated' Irish Times (Belfast, 24 August 2011) <www.irishtimes.com/news/over-10-000-tonnes-of-waste-to-be-repatriated-1.604938>.

108 The Mills Report in 2013 (n 12) reported that the DOE had calculated that it had prosecuted 454 offenders for the dumping of illegal waste since 2003. Very little of this waste appears to have been removed or remediated. The report found that, assuming that a risk assessment required the removal of waste from 100 of these sites, with an average volume of $10,000 \mathrm{~m} 3$ and a removal cost of $f^{215} / \mathrm{m} 3$ (based on the repatriation of waste to the Republic of Ireland project), it would cost the Northern Ireland taxpayer $£ 250$ million. The estimated amount of illegal waste at the Mobuoy Road site has been reported in the Assembly and by the NIEA Stakeholders Group in November 2015 as a volume of 1,165,155m3, crudely equating to a weight of one-and-a-half-million tonnes. Whilst the estimated tonnage of illegal waste has risen at the Mobuoy Road site, there is confusion as to the final clean-up bill. The Executive and Northern Ireland Stakeholders Group have estimated clean-up costs at this site alone to be between $£, 40$ million and $£, 140$ million, pending an agreed remediation plan. As well as Mobuoy, the NIEA currently has a further 89 enforcement cases at various stages in the investigative/legal process, involving, approximately 561,644 tonnes of waste the clean-up costs of which can crudely be estimated to amount to a further $f, 50$ million. Details of ongoing cases provided by NIEA to author via email (9 December 2015).

109 Adrian Rutherford, 'Illegal Fuel Plants Bankrolling the Dissidents, Polluting Rivers and Endangering Lives' Belfast Telegraph (Belfast, 10 February 2015) <www.belfasttelegraph.co.uk/news/northern-ireland/illegal-fuelplants-bankrolling-the-dissidents-polluting-rivers-and-endangering-lives-30978239.html $>$. This figure did not include the clean-up costs of toxic material produced at fuel plants, which had to be removed following raids.

110 Ibid.

111 NIAO, 'Protecting Strangford Lough' (Report by the Comptroller and Auditor General 31 March 2015).

112 HL Deb 15 July 2014, vol 755, col 501, Question: Northern Ireland: Illegal Petrol and Diesel' <www.publications.parliament.uk/pa/ld201415/ldhansrd/text/140715-0001.htm\#14071553000425>. 
disposal, based on the quantities already discovered at illegal dumps, the lost revenue from avoided landfill taxes and charges could be crudely estimated as between f,100-135 million. ${ }^{113}$ The Quarry Products Association has estimated that illegal quarrying costs the exchequer at least $f^{2}$ million per year in lost VAT and Aggregates Levy ${ }^{114}$ and the NIAO is also currently investigating the issuance of millions of pounds in tax credits through the Aggregate Levy Credit scheme (ALCS) to extraction companies which could have been operating without all necessary planning and environmental consents. ${ }^{115}$

In addition to the direct costs associated with remediating environmental damage, environmental governance failures have also created a situation where Northern Ireland is seemingly at perpetual risk of infraction proceedings from the EU. As previously highlighted, although the UK as a whole would be found to be in breach of EU environmental directives should such a breach be identified, it would be the devolved government that would be liable to pay the cost of any fines imposed as a result of failure to transpose EU law. ${ }^{116}$ Such financial sanctions may consist of both a daily penalty to induce the remedy of the breach (of up to circa $€ 237,864$ per day, a figure which is then multiplied by the duration of the breach) and a lump sum (based on an assessment of the effects of the breach for which the minimum for the UK is currently €9,982,000). ${ }^{117}$ Given the UK's impending exit from the EU, it is unclear at what stage the 'cut-off' point for infraction proceedings will be, but until Brexit actually occurs EU law still applies. As of June 2016, there were ongoing infraction cases being brought by the European Commission in respect of breaches of the Water Framework Directive, Waste Framework Directive, Habitats Directive, Strategic Environmental Assessment Directive, Environmental Impact Assessment Directive and Urban Waste Water Treatment Directive. ${ }^{118}$ Failure to deal with the legacy of illegal dumping specifically could also attract very significant infraction fines. ${ }^{119}$ In addition, there have also been concerns raised in the Northern Ireland Assembly about Northern Ireland potentially being in

113 It is impossible to evaluate the exact landfill tax that has been lost with any accuracy as the precise tonnage of waste dumped is unclear and not all the waste that has been buried would have been subject to landfill tax. A crude estimation, if closer to one-and-a-half million tonnes has been buried at Mobuoy Road, is that the lost tax revenue could be over $£, 100$ million. Adding the further 561,000 tonnes of waste that has been discovered at the other 89 NIEA enforcement cases at various stages in the investigative/legal process, then this could potentially add another $£ 35$ million to the total figure of tax evaded.

114 Figure supplied by the Quarry Products Association to the authors by email (7 December 2015).

115 Freedom of Information Request about Aggregates Levy Credit Scheme from the DOE (including spreadsheet register containing information on applicants for an Aggregates Levy Credit Scheme Certificate, also letter regarding copies of documentation) (6 August 2014, copy on file with authors).

116 See n 65 above.

117 Communication from the Commission: 'Updating of Data Used to Calculate Lump Sum and Penalty Payments to Be Proposed by the Commission to the Court of Justice in Infringement Proceedings' (C 257/01, $2015)<$ http://eur-lex.europa.eu/legal-content/EN/TXT/?uri=CELEX\%3A52015XC0806(01)>.

118 Official Report: Minutes of Evidence Committee for Agriculture, Environment and Rural Affairs, meeting on Thursday 16 June 2016 <http://aims.niassembly.gov.uk/officialreport/minutesofevidencereport.aspx? AgendaId=18395\&eveID=10674>.

119 Mills (n 12) also concluded that any failure to deal with the legacy of the illegal waste sites could risk infraction under the EU Waste Framework Directive. There are case precedents that indicate that if proper clean-up operations are not undertaken then this could result in heavy fines from Europe until rectified. See, for example, Case C-494/01 Commission v Ireland and Case C387/92 Commission v Greece. In Case C-196/13 Commission v Italy, Italy was fined $€ 40$ million for failing to tackle the dumping of illegal waste. The court also said it would impose further penalties of $€ 42.8$ million for every six months Italy failed to clean up its legacy of hundreds of waste dumps. 
breach of the Nitrates Directive, ${ }^{120}$ Safe Storage of Metallic Mercury Wastes Directive, ${ }^{121}$ Wild Birds Directive ${ }^{122}$ and Marine Strategy Framework Directive ${ }^{123}$ - all of which could potentially lead to further infraction proceedings. Domestic legal action also poses a potential financial risk. Under the Aarhus Convention, if a government is perceived to not be meeting its legal obligations, then public interest groups can access the justice system and compel it to act. ${ }^{124}$ The financial implications of going to court can be very high and resource-intensive, negative media can be generated, and it can shine a spotlight on the fact that the Executive is not acting. ${ }^{125}$

Less tangible are the financial benefits lost to Northern Ireland as a result of weak environmental governance. Protecting the environment is not a one-way cost and there has been very little recognition in Northern Ireland of some of the serious economic impacts that current systems of environmental governance are having. A key issue here is the potential impact on foreign direct investment (FDI). Weak environmental regulation and the failure to uphold the rule of law present critical disincentives to FDI, where a top priority for investors in the last five years has been 'stability and transparency of political, legal and regulatory environment'. ${ }^{126}$ The creation of unfair competition from illegal operators distorts markets and undermines the development of sustainable industries, most notably in Northern Ireland across the waste industry. ${ }^{127}$ The cost of regulating such high levels of non-compliance also inevitably increases the regulatory bill and puts further pressure on an already overstretched criminal justice system. Problems with an unstable and unfair regulatory playing field have been exacerbated by a painfully slow system for gaining planning permission. ${ }^{128}$ In addition, it is well established that Northern Ireland is at risk of infraction proceedings from Europe arising from a lack of investment in waste-water treatment plants. ${ }^{129}$ If treatment works are operating at, or close to capacity, new businesses cannot be connected to the plant, unless the plant's capacity is extended. So, non-compliance with environmental laws, in terms of

120 Northern Ireland Assembly, Session 2012/2013, 'Report on Statutory Committee Activity on European Issues’ May 2011-August 2012, NIA 81/11-15 (21 November 2012).

121 Northern Ireland Assembly, Session 2012/2013, Committee for the Environment, Minutes of Proceedings, 14 March 2013.

122 Northern Ireland Assembly, Assembly Business, Office Report, Reports 11-12, 5 March 2012 <www.niassembly.gov.uk/assembly-business/official-report/reports-11-12/05-march-2012/>; Northern Ireland Assembly, Assembly Business, Office Report, Reports 12-13, 21 January 2012 <www.niassembly.gov.uk/assembly-business/official-report/reports-12-13/21-january-2013/>.

123 Northern Ireland Assembly, Assembly Business, Session 2011/2012, Committee for the Environment, Report on the Marine Bill, NIA 57/11-15 (5 July 2012).

124 William Orbinson, 'The Aarhus Convention in Northern Ireland: A Tale of Two Polities' in Charles Banner (ed), The Aarbus Convention: A Guide for UK Lawyers (Hart 2015) 73.

125 An example of an ongoing case relates to sand dredging in Lough Neagh. Friends of the Earth (NI) is challenging the DOE's failure to stop companies from illegally extracting sand from this protected area <http://www.bbc.co.uk/news/uk-northern-ireland-38500893>.

126 Ernst and Young, 'EY's Attractiveness Survey: Europe 2015 - Comeback time' (EYGM Ltd 2015) $<$ www.ey.com/gl/en/issues/business-environment/ey-european-attractiveness-survey-2015>.

127 Mills (n 12).

128 For example, the nine-year planning controversy surrounding the John Lewis development in Sprucefield, Jim Fitzpatrick, 'John Lewis: Questions Raised as Retailer Abandons Sprucefield Plan' BBC News (1 February 2013) <www.bbc.co.uk/news/uk-northern-ireland-21291369>.

129 Northern Ireland Assembly, Assembly Business, Session 2014/2015, Executive Committee Business, 10 June 2014 <www.niassembly.gov.uk/assembly-business/minutes-of-proceedings/tuesday-10-june-2014/>; Northern Ireland Assembly, Assembly Business, Session 2014/2015, Committee for Regional Development (8 October 2014) <www.niassembly.gov.uk/globalassets/documents/regional-development/minutes/20142015/20141008.pdf>. 
investments in strategic infrastructure, also presents serious challenges to FDI and economic growth. A further risk created by a damaged environment relates to potential damage to the tourist economy in Northern Ireland (worth $f^{7}, 23$ million annually to the economy and sustaining 43,000 jobs). ${ }^{130}$ High-profile TV and film production in Northern Ireland is also placed in jeopardy when the natural environment which has attracted that industry in the first place is damaged or at risk. ${ }^{131}$

In addition to serious environmental and economic consequences, the centralised nature of environmental governance and political profligacy towards environmental concerns in Northern Ireland have enfeebled the development, culture and campaigning approach of the many within the ENGO community operating in this jurisdiction. An underdeveloped ENGO sector with a traditional focus on local environmental justice issues is arguably a feature of civil society on the island of Ireland ${ }^{132}$ and the diminution of environmental movements in post-conflict societies is a well-recognised phenomenon. ${ }^{133}$ However, the situation in Northern Ireland has been compounded by apparent reluctance of many within the ENGO sector to engage in high-profile public criticism of environmental policy and regulatory efforts. ${ }^{134}$

There are a number of reasons for this. First and foremost, many ENGOs rely on funding from the government department within which the environmental regulator is located and to publicly object to any aspect of the regulator's performance could create at least a perception that criticism might place that funding in jeopardy. ${ }^{135}$ Secondly, given the small scale of regulatory operations within the NIEA, it is easy for criticism to become highly personalised. This arguably creates an aversion to engaging in openly confrontational campaigning tactics which is intensified by the cross-pollination between existing and former government senior staff now highly placed within governance and management frameworks of ENGOs. ${ }^{136}$ Thirdly, in the absence of a robust and vocal environmental champion (i.e. an independent environmental regulator), the 'operational risks and organisational burdens'137 associated with environmental lobbying in Northern Ireland have been exponentially increased. This means that, on the one hand, there is a

130 The tourist economy in Northern Ireland, NI Business Info <www.nibusinessinfo.co.uk/content/touristeconomy-northern-ireland $>$.

131 For example, the production of HBO's Game of Thrones series which has attracted thousands of visitors to key natural environment features such as the Dark Hedges in Co Antrim. It has been estimated that $£ 150$ million of additional revenue has been created across the six years that the series has been filmed in Northern Ireland, <www.bbc.co.uk/news/uk-northern-ireland-36749938>.

132 See Liam Leonard, The Environmental Movement in Ireland (Springer 2007) and John Barry and Peter Doran, 'Environmental Movements in Ireland: North and South' in John McDonagh, Tony Varley and Sally Shorthall (eds), A Living Countryside: The Politics of Sustainable Development in Rural Ireland (Ashgate 2009) 321-41; Liam Leonard, Honor Fagan and Peter Doran, 'A Burning Issue? Governance and Anti-incinerator Campaigns in Ireland, North and South' (2009) 18(6) Environmental Politics 896-916.

133 Adam Fagan, 'Neither "North" nor "South": The Environment and Civil Society in Post-conflict BosniaHerzegovina' 15(5) Environmental Politics 787-802.

134 Turner and Brennan (n 10) 513.

135 A report by the Building Change Trust and Ulster University on the voluntary sector in Northern Ireland found that 'some organisations are moderating their critique of government or policy directions, often out of fear of losing funding': Independence of the Voluntary Community and Social Enterprise Sector in NI: Finding a New Story to Tell (Building Change Trust and Ulster University 2016). See also, Northern Ireland Environment Link, Funding and the Environmental NGO Sector in Northern Ireland (Report of Proceedings, 6 December 2010) <http://www.nienvironmentlink.org/cmsfiles/files/events/eNGO-6-decFINAL.pdf>.

136 Interview by the authors with James Orr, head of Friends of the Earth NI, 6 March 2017. See also, J Barry, "'It Ain't Easy Being Green": Sustainable Development between Environment and Economy in Northern Ireland' (2009) 24 Irish Political Studies 45-66.

137 Turner and Brennan (n 10) 513. 
far weightier responsibility placed on ENGOs to act in a scrutiny and lobbying role and, on the other hand, creates far higher stakes for doing so. ${ }^{138}$ There is a perception that some ENGOs have lost some of their distinctiveness and independence and have become (or are becoming) like an arms-length public body that is only consulted, and listened too, on a selective basis by government.

Evidence of the Northern Irish ENGO community's vulnerability to political developments is replete throughout the history of the governance debate. In the mid2000s a high-profile public campaign for an IEPA brought together nine of Northern Ireland's most influential ENGOs in an unprecedented cooperative attempt to influence decision-making on environmental governance. ${ }^{139}$ Despite effectively lobbying the direct rule government into agreeing to undertake a review of environmental governance, once devolution was reinstated after a period of suspension, the devolved government unceremoniously rejected the findings of the independent review panel when the DUP blocked the externalisation of environmental regulation to an IEPA. ${ }^{140}$ The ability of one party to essentially steamroll over the combined efforts of the ENGO coalition (which, it should be noted, had the support of all other political parties) coupled with the desultory manner in which years of work had been nullified led to the rapid disintegration of the coalition and ushered in a period of dejection and timidity in environmental lobbying. A brief flurry of lobbying activity followed in the wake of funding cuts in 2014, but once funding was reinstated many in the ENGO community once again seemed placated. ${ }^{141}$ The merging of the DOE and DARD into the new DAERA in 2016 was accompanied by significant concerns, particularly in relation to the regulation of agricultural pollution. ${ }^{142}$ These concerns, coupled with the removal of the political need to preserve the DOE's core workload and some political support for re-examining the idea of establishing an IEPA led to a recent reignition of ENGO activity in the environmental governance debate. Since the collapse of the devolved government, however, the lobbying activity of many government-funded ENGOs seems to have once again diminished. 143

\section{Environmental governance in a shifting political landscape}

Given the scale of the problems experienced in Northern Ireland and the severe consequences of environmental governance failures, it is clear that urgent reform is now

138 Ibid.

139 The coalition consisted of the Conservation Volunteers, Friends of the Earth, the National Trust, Northern Ireland Environment Link, the Royal Society for the Protection of Birds (RSPB), the Ulster Wildlife Trust, the Wildfowl and Wetlands Trust, the Woodland Trust and World Wide Fund for Nature. The campaign commissioned Professor Richard Macrory to undertake an evaluation of environmental governance arrangements in Northern Ireland. See Macrory (n 9). For a full discussion of the NGO campaign, see Turner and Brennan (n 10).

140 Turner and Brennan (n 10) 517-20.

141 Interview with $\operatorname{Orr}$ (n 136).

142 John Manley, 'Agreeing UFU Farm Pollution Proposal Would Be "Folly" Says Former Minister Mark H Durkan' Irish News (Belfast, 16 August 2016) <www.irishnews.com/news/2016/08/16/news/agreeing-ufufarm-pollution-proposal-would-be-folly-says-former-minister-653605/>.

143 An environmental governance 'working group' was established by Friends of the Earth, the National Trust and RSPB in 2015, with the goal of commissioning some up-to-date research into environmental governance in Northern Ireland. The group commissioned a team of independent consultants (including two of the present authors) to undertake a detailed review of environmental governance arrangements and identify ways in which environmental governance could be reformed and developed. The report's findings relating to the scale of the consequences of weakened environmental governance proved politically sensitive and the mechanics of what parts of and how the report would be published also led to significant discomfort amongst the commissioning ENGOs. As of 7 July 2017, the report remains unpublished. 
required. Not only is there a need to address the serious environmental impact of years of neglect and stem the tide of environmental damage still occurring because of noncompliance with environmental law, but the economic consequences of governance failures are also looming. However, given the seismic political shifts occurring not only in Northern Ireland, but on the island of Ireland, within the UK, Europe and beyond, there is a need to contextualise these problems and any suggestions for reform in the face of wider political developments. On a local level, while the collapse of the Stormont administration in December 2016 has created significant uncertainty about the future of devolved politics in Northern Ireland, it may also present an opportunity to re-insert the issue of an IEPA into political discussions. ${ }^{144}$ The DUP's loss of the controversial petition of concern might at least offer an opportunity for other political parties which support the proposition of an arms-length regulator to achieve this long-gestating ambition should an Executive be formed. ${ }^{145}$ However, with significant doubt remaining as to how the political situation in Northern Ireland will unfold in the short to medium term (especially given concerns surrounding the DUP-Conservative political deal in the wake of the June 2017 Westminster elections), forming a stable government is a challenge that must be overcome first. ${ }^{146}$ With negotiations surrounding issues such as an Irish Language Act, legacy inquest funding, marriage equality and a referendum on Irish reunification leading the list of negotiating terms for Sinn Féin, and the DUP focused on stemming the nationalist voting resurgence displayed in the 2016 Assembly elections and delivering the portfolio of economic benefits controversially negotiated in exchange for supporting the Conservative government, there is a risk of environmental governance once again being sidelined from mainstream political debate. ${ }^{147}$ Alternatively, should one of the main political parties recognise the importance of the issue and add it to their negotiating terms, the political disarray might offer an opportunity to raise the issue up the political agenda. In the event of the re-establishment of UK direct rule or some form of combined rule from Dublin and London, questions surrounding who will 'foot the bill' for the legacy of environmental governance dysfunction in Northern Ireland may play a prominent role - not least the continuing prospect of EU infraction fines.

While there is obviously a need to consider Northern Ireland, all-island and UK political dimensions to the environmental governance debate, any suggestions for reform must clearly take account of direct and tangential consequences of the Brexit process. Here, the form of the UK's Brexit deal (presuming one is actually negotiated) will dictate

144 At the time of writing (early July 2017) no agreement to form an Executive in Northern Ireland had yet been reached.

145 David Young, 'DUP Loses “Petition of Concern” Veto Power at Stormont' Irish News (4 March 2017) $<$ www.irishnews.com/news/assemblyelection/2017/03/04/news/dup-loses-petition-of-concern-vetopower-at-stormont-952707/>. In brief, the petition of concern means any proposal before the Northern Ireland Assembly must be supported by a majority of both nationalist and unionist MLAs rather than a simple majority. To be valid, a petition of concern must have signatures of 30 MLAs. Prior to the 2017 Assembly elections, the DUP could unilaterally table a petition of concern because, with 38 seats, it was the only party with the required 30 signatures. In the 2017 election, this power was lost as the DUP only succeeded in winning 28 seats <www.bbc.co.uk/news/election/ni2017/results>.

146 The full agreement and supporting documents are available at <www.gov.uk/government/publications/conservative-and-dup-agreement-and-uk-government-financialsupport-for-northern-ireland $>$. The 'confidence and supply' deal has been criticised by both UK opposition parties and Northern Ireland parties as having the potential to breach, or at least undermine, the terms of the Good Friday Agreement as well as having a negative impact on the failed talks aimed at re-establishing the Stormont Executive which collapsed in early July 2017. Julian O'Neill, 'Stormont Talks: Brokenshire to "reflect" Amid Ongoing Deadlock' Irish News (Belfast, 4 July 2017) <www.bbc.co.uk/news/uk-northernireland-40489510>.

147 Ibid. 
the future of environmental law in the UK and ultimately the degree to which the devolved governments can diverge from current standards of protection. ${ }^{148}$ At the time of writing, this remains shrouded in significant uncertainty. ${ }^{149}$ A critical issue will be whether the UK remains part of the Single Market, which will dictate the extent to which the UK must continue to comply with EU environmental directives. ${ }^{150}$ If the UK remains part of the European Economic Area it will still be bound by many EU laws, including significant environmental directives such as the Waste Management Directive and the Water Framework Directive, but the UK's ability to influence future development and changes to environmental standards would be removed. ${ }^{151}$ In principle this would limit the UK's ability to introduce variations to its own environmental standards and, because most environmental matters are devolved, would also prevent devolved administrations embarking on 'solo-runs' as ultimately large swathes of environmental management would still be subject to EU law. ${ }^{152}$

Conversely, and although still constrained by the UK's international legal obligations, should the UK leave the Single Market much of the legal requirement to comply with EU environmental law could be removed. Although this would be substantially mitigated by the UK's international obligations and any new arrangements negotiated as part of the Brexit agreement, the possibility of any reduction in standards of protection derived from EU law and policy has generated significant concern amongst environmentalists. ${ }^{153}$ In evidence to the UK's Environmental Audit Committee, stakeholders have expressed fears that Brexit could lead to environmental law becoming diluted in order to reduce regulation and enhance the UK's competitiveness, ${ }^{154}$ despite recent Conservative party assurances to the contrary. ${ }^{155}$ Given that the DUP's 2017 election manifesto contained no reference whatsoever to the environment and its (and the Conservative government's) history of a preference for light-touch environmental regulation, ${ }^{156}$ the prospect of unfettered devolved ability to vary environmental standards is cause for significant concern in the local context. A UK 'bonfire of regulations' would also necessarily result in EU counter-measures which could be highly detrimental to, for example, trade between

148 As of July 2017, there remains significant uncertainty surrounding not only the UK government's approach to the Brexit negotiations, but also the stability of the Conservative government which failed to secure a majority in the Westminster elections in May 2017 and has since recruited the DUP in a 'supply and demand' arrangement in order to cling on to power (n 146).

149 As of July 2017.

150 Richard Macrory, 'Brexit Unlikely to Give UK Free Rein over Green Laws' (ENDS Report 499, September 2016).

151 David Baldock, Andrew Farmer and Martin Nesbit, Brexit: The Implications for UK Environmental Policy and Regulation (Institute for European Environmental Policy, March 2016) <https://www.ukela.org/content/page/5736/IEEP_2016_Brexit_-_Implications_for_UK_Environmental_ Policy_and_Regulations.pdf $>7$.

152 Colin Reid, 'Environmental Law Outside the EU' The Journal (18 July 2016) <www.journalonline.co.uk/Preview/1021967.aspx\#.WWY3iljysdU>.

153 Colin Reid, 'Brexit and the Future of UK Environmental Law' (2016) 34(4) Journal of Energy and Natural Resources Law 407-15.

154 Environmental Audit Committee, EU and UK Environmental Policy, 23 March 2016 (HC 2015-16, 537), cited in House of Commons, Brexit: Impact Across Policy Areas (Briefing Paper Number 07213, August 2016) $<$ http://researchbriefings.parliament.uk/ResearchBriefing/Summary/CBP-7213\#fullreport> 75.

155 Roger Harribin, 'Brexit Will Enhance Wildlife Laws - Gove' BBC News (19 June 2017) <www.bbc.co.uk/news/science-environment-40331919>.

156 Matthew Taylor, "Michael Gove as Environment Secretary is "Fox in Charge of Hen House" The Guardian (London, 12 June 2017) <www.theguardian.com/politics/2017/jun/12/michael-gove-entirely-unfit-to-beenvironment-secretary-says-greens $>$. 
Northern Ireland and the Republic of Ireland. ${ }^{157}$ Media have reported that the UK government's threats to becoming a low tax, low regulation state in the absence of an agreement on market access 158 have already prompted the European Parliament to consider mechanisms through which any exit deal would essentially hinge upon UK maintenance of existing environmental standards and that this could be enforced through a pan-European court of arbitration. ${ }^{159}$ Whether any enforcement mechanisms bestowed upon this court would result in devolved government financial liability for fines imposed in response to falling environmental standards would clearly be a significant driver for ensuring UK-wide compliance. ${ }^{160}$ A connected risk is that divergence across the constituent parts of the UK would lead to a very problematic degree of fragmentation of environmental law regimes across the UK were no alternative 'brake' put on this process. ${ }^{161}$ This could create further uncertainty for business and complicate the administration and delivery of environmental regulation.

A further issue relates to the impact of Brexit on the border between Northern Ireland and the Republic of Ireland. Identified by the EU as one of the crucial issues to be addressed in the Brexit negotiations, the difficulties and opportunities associated with how changes to the nature of the border will affect environmental governance are a prime example of the type of complex questions that will need to be addressed by Northern Irish politicians in conjunction with the Irish and British governments and the EU as the Brexit process evolves. The transboundary nature of many environmental problems, coupled with the inherent need to cooperate with neighbouring jurisdictions to ensure environmental protection is explicitly reflected in the provision for cross-border environmental governance enshrined in the Good Friday Agreement. ${ }^{162}$ For example, Strand Two acknowledges the crucial importance of cross-border governance relationships and establishes formal cooperation across a number of areas, including the environment. ${ }^{163}$ This reflects a clear recognition that close cooperation between neighbouring jurisdictions can create 'significant synergies and deliver beneficial environmental outcomes more cost-effectively'. ${ }^{164}$ While there are strong arguments for enhancing cross-border environmental governance given the significant and very similar problems faced on either side of the border and the cross-border nature of issues like waste crime and river basin management, this has become problematised by the Brexit

157 Peter Walker, 'Andrea Leadsom Promises Brexit Bonfire of Regulation for Farmers' The Guardian (London, 4 January 2017) <www.theguardian.com/politics/2017/jan/04/andrea-leadsom-vows-to-scrap-eu-red-tape-forfarmers-after-brexit $>$.

158 Philip Oltermann, 'Hammond Threatens EU with Aggressive Tax Changes after Brexit' The Guardian (London, 15 January 2017) <www.theguardian.com/politics/2017/jan/15/philip-hammond-suggests-ukoutside-single-market-could-become-tax-haven>.

159 Daniel Boffey, 'MEPs in Bid to Force UK to Meet Environmental Regulations after Brexit' The Guardian (London, 31 January 2017) <www.theguardian.com/politics/2017/jan/31/european-parliament-force-ukmeet-environmental-regulations-after-brexit>.

160 Northern Ireland is currently responsible for paying any EU infraction fines imposed as a result of nontransposition or implementation of EU directives, as discussed previously ( $n$ 65).

161 Reid (n 153).

162 Good Friday (Belfast) Agreement 1998, Strand 2 <www.gov.uk/government/ uploads/system/uploads/attachment_data/file/136652/agreement.pdf >.

163 Ibid.

164 Burke et al (n 9) 32. 
process which also clearly places existing cross-border measures in jeopardy. ${ }^{165}$ If Northern Ireland's environmental law diverges from the Republic of Ireland's EU-based legal frameworks in the future then transboundary environmental governance will become more difficult as institutional architectures and standards become potentially more diverse. ${ }^{166}$ For example, differences in the structures and approaches to enforcement adopted either side of the border have in the past created regulatory gaps which have facilitated illegal cross-border environmental crime to germinate and flourish. ${ }^{167}$ Management of river basins which transcend the border will also require enhanced cooperation and careful consideration of cross-border policy impacts. These issues have the potential to be magnified, dependent on the nature of Brexit and the political situation in Northern Ireland, and there is clearly a need for further, detailed investigation into what retention of the status quo (i.e. a 'soft' border), imposition of a customs/physical ('hard') border, or removal of the border altogether might mean for overall success or failures of any future environmental governance arrangements or law reforms.

The prospect of Brexit has also thrown the role that the EU has played in the context of environmental protection to date into sharp resolution. Although there is a risk of viewing what is considered an imperfect EU environmental law framework (particularly the compliance and enforcement regimes) ${ }^{168}$ with a sense of 'nostalgia', in the Northern Ireland context the EU has played an undeniably important role. ${ }^{169}$ Lee has identified three key functions that the EU has fulfilled to date in the context of the UK environment as 'the big sticks of Commission-plus-Court of Justice enforcement mechanisms and fines, but also a more subtle architecture of transparency and political accountability, as well as a series of EU legal principles that render judicial review before domestic courts more effective'. ${ }^{170}$ In the Northern Ireland context, possibly the most obvious role of the EU in the context of environmental law has been its enforcement function. Despite the slow pace of EU enforcement procedures, they can (and have) resulted in the imposition of significant infraction fines ${ }^{171}$ and the threat of these has proven crucial in forcing the Northern Irish government to introduce and attempt to maintain environmental standards. ${ }^{172}$ Importantly, the European Commission can instigate infraction proceedings for not only failure to transpose directives, but in situations where they have not been implemented correctly or applied properly in practice. Jack highlights the case of Commission $v$ Ireland $^{173}$ as demonstrative of how the

165 The Republic of Ireland has also experienced significant environmental governance, and particularly environmental regulation problems. See, for example, George Taylor, 'Conserving the Emerald Tiger: The Politics of Environmental Regulation in Ireland' (1998) 7(4) Environmental Politics 53-74; Aine Ryall, 'Delivering the Rule of Environmental Law in Ireland: Where Do We Go from Here?' in Suzanne Kingston (ed), European Perspectives on Environmental Law and Governance (Routledge 2012).

166 The difficulties associated with transboundary environmental governance have been explored in Richard Macrory and Sharon Turner, 'Participatory Rights, Transboundary Environmental Governance and EC Law' (2002) 39(3) Common Market Law Review 489-522.

167 Brennan (n 2) 479.

168 M Hedemann-Robinson, Enforcement of European Union Environmental Law (Routledge 2015).

169 Robert Lee, 'Always Keep a Hold of Nurse: British Environmental Law and Exit from the European Union' (2017) 29 Journal of Environmental Law 155.

170 Maria Lee, 'Accountability for Environmental Standards after Brexit' (2017) 19(2) Environmental Law Review 89-92.

171 In December 2014 Italy was fined over $€ 40$ million in EU infraction fines subsequent to the European Court's decision in Case C-196/13 Commission v Italian Republic, ECLI:EU:C:2014:2407.

172 Brennan (n 2) 479.

173 Case C-494/01 Commission v Ireland. 
Court of Justice of the EU (CJEU) has applied the concept of a 'general and persistent breach' in 'bad application' cases. ${ }^{174}$ In this case, Ireland was found to have failed to fulfil its Waste Framework Directive obligations by allowing illegal waste disposal sites to continue operations. Importantly, the CJEU found that, in order to avoid financial penalties, the general and persistent failure to enforce EU law would mean that Ireland must not only address the operation of the sites themselves, but the underlying systemic failures that had facilitated their existence. ${ }^{175}$ In Northern Ireland there are clearly similar issues and the spectre of infraction fines has historically forced the devolved government to try and deal more effectively with, for example, serious cross-border waste crime. ${ }^{176}$ If this threat was removed, serious questions would emerge as to where the impetus for the devolved government to maintain and enhance environmental protection efforts would stem from.

\section{Pathways to effective environmental governance}

With these considerations in mind, reforms must now take place across the three areas identified at the outset of this analysis, i.e. environmental governance structures, environmental law and policy, and regulatory practice. Firstly, the NIEA should be located outside a central government department and be given the status of a non-departmental public body. Although not a panacea for the myriad problems that have characterised the experience of regulating the environment in Northern Ireland, the establishment of an IEPA would at least inject some much needed credibility into regulatory efforts in the wake of years of scathing criticism. A particular advantage of removing the regulatory function from central government would be to alleviate concerns surrounding the potential for political interference in regulatory decision-making and enhance public trust in environmental regulation. ${ }^{177}$ While not removing the risk of agency capture, locating the regulator at arms-length distance of a central government department would mitigate the degree of influence that industry (particularly the agricultural industry under the current arrangements) and politicians currently have the opportunity to exert. ${ }^{178}$ The core rationale for this important structural change is well documented, but, given the political uncertainty that surrounds both the UK's impending exit from the EU and the collapse of the devolved administration, there is an urgent need to ensure environmental protection can continue despite the surrounding political turmoil. Not only would making this change insulate environmental protection from other political imperatives, but it would bring the governance arrangements in this jurisdiction into line with those operating both in other parts of the UK and the Republic of Ireland. Whilst the initial costs of creating and resourcing an independent agency might have short-term financial consequences and provoke opposition within the Executive, there should be significant benefits to both the environment and economy in the long term. The ability to engage more strategically and systematically might also lead to stronger and more consistent and transparent enforcement and it would allow for the streamlining and integration of functions. A higher degree of independence should also allow greater flexibility in making the necessary changes to speed up decisions and actions. An IEPA might also provide more visibility to environmental guardianship, becoming an identifiable champion for the protection and

174 Jack (n 62) 154.

175 Ibid.

176 Brennan (n 2) 482.

177 The CJI has recommended that clear procedures must be in place to ensure independence of regulatory function, so that enforcement staff are not subject to political and other internal/external pressures: CJI (2011) (n 8).

178 Lowe et al (n 38). 
improvement of the Northern Ireland environment, as opposed to just another limb of a government department with multiple (and sometimes conflicting) portfolios.

A further structural innovation should be reform of the oversight bodies designed to hold the government to account in environmental matters. Within government, the Stormont Committee for Agriculture, Environment and Rural Affairs has replaced two previous committees, one of which dealt solely with the environment. ${ }^{179}$ Given the potential conflicts between the regulation and support of the agricultural community in the wake of this merger, the performance of DAERA should be subject to ongoing review and one possible solution would be to establish an environmental (and sustainable development) audit committee in the Northern Ireland Assembly. In England, there is a House of Commons Environmental Audit Select Committee in addition to a separate Commons Select Committee on the Environment, Food and Rural Affairs. ${ }^{180}$ The Environmental Audit Committee's role is to consider to what extent the policies and programmes of government departments and non-departmental public bodies (NDPBs) contribute to environmental protection and sustainable development and to audit their performance against government targets (and to report the findings to the House of Commons). ${ }^{181}$ Having such a Committee in Northern Ireland should result in better environmental integration and ensure that departments are carrying out their functions within environmental limits. In addition, the environmental investigation capacity of other scrutiny bodies outside of government could be enhanced. The NIAO and the CJI in particular have to date provided valuable insights into the scale of the problems surrounding environmental governance in Northern Ireland. ${ }^{182}$ Both bodies could establish small dedicated internal teams to focus on environmental concerns and increase scrutiny of the performance of key environmental governance structures such as the NIEA or an independent regulator.

Secondly, measures should also be taken to ensure that there is a more integrated and strategic plan to protect Northern Ireland's environment. There should be an overarching strategy on the protection of the environment in one single document, which contains strategic priorities of the Executive and outcomes to be aimed at, and be written in a style that is easily understandable. There should also be a review of institutional arrangements encompassing an examination of who does what and why, where integration between sectors and other departments applies and where it needs to be strengthened. In the absence of an independent environmental regulator, a Commissioner for the Environment could be established to ensure effective implementation and application of environmental law. Commissioners for human rights, police, children and older people have all been established in Northern Ireland and these offices have in general achieved a high level of success. An Environment Commissioner could be appointed to oversee the implementation and correct application of all EU environmental laws and to oversee sustainable development in Northern Ireland. ${ }^{183}$ While significant streamlining of environmental regulation should be achieved as the integrated permitting regime

179 Details of the Northern Ireland Assembly Committees formed during the 2016/2017 mandate are available at <www.niassembly.gov.uk/assembly-business/committees/2016-2017/>.

$180 \mathrm{~A}$ full list of the committees is available at <www.parliament.uk/business/committees/committees-a-z/>.

181 The role of the Environmental Audit Committee is outlined at <www.parliament.uk/business/ committees/committees-a-z/commons-select/environmental-audit-committee/role/ $>$.

182 CJI 2007, CJI 2011 and CJI 2015 (n 8) and NIAO (n 5).

183 Northern Ireland previously had a Sustainable Development Commission, but this was dismantled during the 'bonfire of the quangos' initiated by the UK Coalition government in 2011 <www.independent.co.uk/news/uk/politics/bonfire-of-the-quangos-bodies-to-be-abolished2107709.html>. 
introduced in 2016 finally comes into force, some further legislative change may also be required, for example, the introduction of more flexible environmental sanctions for responding to breaches of environmental law. ${ }^{184}$ In addition, an expert independent special advisor should also be appointed by the Minister of DAERA in support of overseeing the implementation and correct application of all EU environmental laws.

In terms of further improvements to strategic planning, a core recommendation of a review undertaken by the Northern Ireland Land Matters Task Force in 2015 is the development and implementation of a Land Strategy for Northern Ireland. ${ }^{185}$ The vision of the Land Strategy is for land and landscapes being managed for the benefit of people's well-being and prosperity, respecting the views of communities, groups and individuals, striving for environmental excellence, and making best use of the environment's multifunctionality. ${ }^{186}$ Before this, there had been very little recognition of the environment as an asset to the Northern Ireland people generally. The proposed strategy would aim to transcend sectoral policies and provide a framework to manage conflicting policy priorities and balance competing demands on land. A Land Strategy coupled with the Regional Development Strategy 2035 should deliver more strategic and consistent decision-making in local councils as they develop their new land-use planning powers and responsibilities gained in 2015. In addition to enhanced scrutiny of environmental decision-making, it might also be beneficial to have an entity in place that ensures effective communication, working relationships and cooperation between central government, local councils and waste management groups and which provides an oversight role to guarantee a strategic approach to land-use planning. Updated, enhanced and more easily accessible overarching strategies relating to environmental protection and sustainable development could also help alleviate the fragmentation of the current policy landscape. ${ }^{187}$

Thirdly, a number of significant improvements must also be made to the delivery of enforcement in practice. As suggested by Burke, Bell and Turner's review of environmental governance in 2006, ${ }^{188}$ advocated by the CJI in 2007, ${ }^{189}$ promised by the then Minister for the Environment in $2008^{190}$ and again reiterated by the CJI in 2011,191 the enforcement function of the NIEA should be delivered by one integrated entity within the NIEA. Given the strategic partnerships developed by the ECU with other enforcement agencies, such as the Police Service of Northern Ireland (PSNI) and the PPS, and the need for a professionalised approach to intelligence and concentration of skills pertaining to criminal and financial investigation, this integrated enforcement body should be structured around the existing ECU, creating a unified, consistent and proportionate enforcement response across all areas in which the NIEA has an enforcement responsibility. Enforcement staff from other units should be transferred to

184 Provision for integrated permitting was introduced by the Better Regulation Act (Northern Ireland) 2016.

185 Northern Ireland Land Matters Taskforce, Towards a Land Strategy for Northern Ireland (Northern Ireland Land

Matters Taskforce 2015) <www.nienvironmentlink.org/cmsfiles/Towards-a-Land-Strategy-for-NI_2015Main-Report.pdf $>$.

186 Ibid 11.

187 The most recent sustainable development strategy was produced in 2010 and, for example, contains no reference to ecosystem services which have become a key paradigm through which to view the benefits that the natural environment can provide to society and the economy. See <www.gov.uk/guidance/ecosystemsservices $>$.

188 Albeit within an IEPA, Burke et al (n 9).

189 CJI 2007 (n 8) 47.

190 Ministerial Statement (n 56).

191 CJI 2011 (n 8) 9. 
this unit in a staggered way over time. This would allow the agency to utilise existing expertise in relation to the various areas of responsibility, but standardise the enforcement response on a pan-agency basis. It would also go some way towards breaking down the entrenched structures within the DOE that have contributed to the inertia that has characterised attempts to reform regulatory structures and practice. As a result, the deterrent effect of the enforcement action carried out by the NIEA would be significantly strengthened. It would also serve the function of creating a degree of separation between the enforcement arm of the agency and the regulatory/compliance-based activities. In addition, being 'referred to the environmental crime unit' could act as a deterrent in itself to the regulated community. One risk of this would be that certain types of environmental offending could become marginalised if they were not classed as being one of the strategic priorities of the unit. However, steps could be taken to mitigate this risk through a priority-setting process and it is unlikely that the net effect of revised arrangements would have a negative impact on areas where little enforcement action is currently occurring. Recruitment of investigative staff with a core enforcement remit rather than scientific officers would reflect the dual role that the NIEA must play and better links with other agencies such as the PSNI, Her Majesty's Revenue and Customs (HMRC), the National Crime Agency (NCA) and law enforcement bodies operating across the border would also be beneficial. ${ }^{192}$

In addition, the NIEA, whether within or independent of DAERA, should embed specialist environmental lawyers into its governance structures. The benefits of employing an in-house legal team are many, but fundamentally the expertise in preparation of case files would be enhanced, alternative and novel charges could be considered and legally trained NIEA staff could act as conduits between the enforcement team and other law enforcement bodies such as the PPS and the NCA where relationships need to be improved across the whole spectrum of environmental offences. In parallel, specialist environmental law prosecutors could be developed within the PPS. The same problems that Northern Ireland is experiencing also frustrated the Scottish Environmental Protection Agency (SEPA) in Scotland for over a decade, but were eventually recognised by the Advocate General who was persuaded in 2011 to appoint lawyers in the Crown Office and Procurator Fiscal Service (COPFS) that specialised in environmental law. ${ }^{193}$ There are now three specialists in wildlife and environmental crime spread across Scotland that work together to share knowledge and experience of cases. In Scotland, the COPFS and SEPA have introduced an agreed protocol on concluding investigations and prosecutions to ensure effective liaison and such a protocol could lessen the gap between enforcement and prosecution that exists in Northern Ireland. ${ }^{194}$

The NIEA should develop a more calibrated and representative enforcement policy and published information relating to the enforcement policy adopted by the agency needs to be enhanced. One approach that could be taken is to follow the example of the

192 There is currently a significant imbalance in the staffing background of the NIEA, with a heavy emphasis on scientific expertise rather than enforcement and investigation. In 2015 the NIEA had 719 FTE staff, with no lawyers. The high-level management structure of the NIEA contains 39 individuals, of whom over half (21) are scientific officers (of some form). Many of the other senior posts were for administrative-type functions like financial officers (6), and there was noticeably only one investigation officer, CJI Northern Ireland 2015 (n 8).

193 <www.crownoffice.gov.uk/about-us/what-we-do/our-role-in-detail/10-about-us/296-specialist-reportingagencies $>$.

194 <www.crownoffice.gov.uk/images/Documents/Prosecution_Policy_Guidance/Protocols_and_Memorandum _of_Understanding/Protocol $\% 20-\% 20$ Submission $\% 20$ Processing $\% 20$ and $\% 20$ Monitoring $\% 20$ of $\% 20$ Prosecution $\% 20$ Reports $\% 20-\% 20$ COPFS $\% 20$ and $\% 20$ SEPA.PDF $>$ 
English Environment Agency (EA) which has published information relating to its enforcement policy in three parts. ${ }^{195}$ Firstly, it has a short enforcement statement that gives an overarching, high-level summary of the principles of enforcement used by the agency in terms of deciding when and what form of enforcement action to take. ${ }^{196}$ This statement is backed up by an enforcement and sanctions guidance document, providing information on the various types of enforcement response available to the agency and details on how it calculates and applies these sanctions and the various associated processes. ${ }^{197}$ Finally, a document detailing the enforcement response options and information on how these will be applied for every offence that falls under the remit of the EA underpins the enforcement statement and guidance. ${ }^{198}$ In Scotland, SEPA also publishes an overarching summary of its enforcement policy and this is backed up by detailed 'supporting guidance' documents relating to specific issues that fall under SEPA's remit and which include a section on enforcement. ${ }^{199}$

In terms of the criminal justice system and environmental prosecutions, one possibility would be to produce updated and more extensive sentencing guidelines. Northern Ireland currently has sentencing guidelines for some environmental crimes. ${ }^{200}$ However, these guidelines only cover five separate offences in the magistrates' courts and provide significantly less detail than the equivalent guidance produced for England. ${ }^{201}$ In 2014, new sentencing guidelines ${ }^{202}$ which apply to the sentencing of various environmental offences in the English magistrates' and Crown courts were published in England by the Sentencing Council. The aim of these new guidelines is to ensure fines have a real economic impact and provide a stronger deterrent to re-offending. The English courts must now consider: making a compensation order for injury or loss or damage resulting from the offence; confiscation; the offence category (culpability and harm); and the tables showing the category ranges when setting a fine. ${ }^{203}$ The range of fines has been vastly increased to reflect an offender's ability to pay. The court will review the sentence as a whole to ensure that any economic benefit that was derived from the offence (for example, avoided costs) has been removed and it is proportionate to the means of the offender to ensure significant economic impact. ${ }^{204}$

Finally, although there is a clear need to improve the delivery of enforcement of environmental law in Northern Ireland, there are other mechanisms that could help improve compliance levels and reduce the need for enforcement activity. In a general sense, cooperation with the regulated community and better (and earlier) provision of education and advice would assist businesses in achieving compliance and avoiding enforcement action. The establishment of a centralised enforcement body within the

195 All documents relating to the EA's enforcement policy are available at <www.environmentagency.gov.uk/business/regulation/31851.aspx>.

196 Ibid.

197 Ibid.

198 Ibid.

199 <www.sepa.org.uk/media/219242/enforcement-guidance.pdf>

200 The guidelines are available at <www.jsbni.com/Publications/sentencing-guides-magistratescourt/Pages/Environment-Offences.aspx>.

201 Ibid. The five offences for which there are currently guidelines are: (i) breach of prohibition notice; (ii) depositing waste without a licence; (iii) discharge/deposit of polluting matter; (iv) treating/keeping or disposing of waste; (v) treating/keeping or disposing of waste likely to cause pollution.

202 Sentencing Council, Environment Offences: Definitive Guideline (2014) <www.sentencingcouncil.org.uk/ wp-content/uploads/Final_Environmental_Offences_Definitive_Guideline_web1.pdf>.

203 Ibid.

204 Ibid. 
NIEA would provide a degree of separation between the enforcement and advice/persuasion elements of the agency to avoid the compromise of any enforcement and deterrent efforts. Alternatively, a separate body to the NIEA could fulfil the education and advice function to ensure a more straightforward separation of these often-conflicting roles. The optimal scenario would be for an IEPA to fulfil the enforcement function, while provision of education, advice and support continued to be delivered by DAERA. In terms of agricultural pollution, while the MOU between DAERA and the UFU has been criticised for its potential to lead to light-touch regulation, weak enforcement and the risk of agency-capture, it might also help foster better links with the agricultural community and facilitate better provision of education and advice. ${ }^{205}$ The controversial aspect of the MOU relates to low severity agricultural pollution incidents and the NIEA's response to this category of pollution. ${ }^{206}$ Under the EU cross-compliance rules relating to subsidy payments to farmers, any pollution will automatically result in an inspection and that can then result in a penalty being applied to a farm's subsidy payment. ${ }^{207}$ The NIEA is seeking permission from the EU to allow farmers who cause low-level pollution to avoid the inspection and receive a fixed penalty notice or mandatory training course instead. While prima facie this seems like a reasonable suggestion and would certainly ease tensions between the NIEA and the agricultural community, the rationale behind the EU rules is significant and particularly so in Northern Ireland. While low-level agricultural pollution incidents are minor on an individual level, the cumulative impact of multiple low-level pollution incidents results in serious diffuse pollution. ${ }^{208}$ The farm subsidies provided to farmers are incentives not to pollute and thus remain the obvious route through which to penalise pollution incidents, regardless of how minor. Removing this aspect of the MOU would make it much less controversial and ensure that robust regulation of agricultural pollution can occur.

In relation to the waste industry, the Mills Report published in 2014 has recognised widespread non-compliance with waste regulation and, clearly, raising compliance levels in this sector would decrease the problem of illegal dumping. ${ }^{209}$ Better liaison, cooperation and information-sharing between the NIEA and local authorities would close enforcement gaps and the agreement of a clear and robust fly-tipping protocol for the entire jurisdiction should be established. The duty of care owed by public authorities in disposal of municipal waste should also be enforced more stringently to ensure reputable companies are being given the business of handling, for example, recycling waste. Enhancement and more robust enforcement of producer responsibility, legislation and recalibration or reconsideration of landfill tax may also be required. ${ }^{210}$ Modernisation of waste regulation systems could also occur and emerging technologies offer new avenues for ensuring compliance. For example, a mandatory electronic duty of a carebased system to replace the current paper-based waste transfer notes could be imposed on operators. Electronic duty of care (eDoc) systems for waste have already been

\footnotetext{
205 Stewart (n 100).
}

206 Conor Macauley, 'Call for Change in Pollution Penalties' BBC News (7 April 2017) <www.bbc.co.uk/news/uknorthern-ireland-39527133>.

207 Details relating to the cross-compliance penalty framework are available at <www.daerani.gov.uk/publications/cross-compliance-penalties>.

208 Cave and McKibbon (n 100).

209 Mills (n 12)

210 For example, legislation could be introduced that would require the waste producer to ensure that the waste company produces licence documentation, information about where the waste is going to go and a certificate showing they have an authorised GPS system to record movements. Offences could be introduced where the waste producer does not adequately undertake these checks. 
successfully developed in England, where they have been free to use and trials saved the companies using them time, effort and money in fulfilling their duty of care requirements for the waste. ${ }^{211}$ Compliance with mineral extraction regulation could be enhanced via a duty on the owner of the land to put up adequate security fencing around disused quarries to stop them being illegally quarried, or to place them under a duty to do regular checks to ensure unlicensed operations are not taking place. More clarity surrounding planning policy guidance, licensing and time limits on quarrying activities could also help alleviate the current problems with illegal mineral extraction.

\section{Conclusion}

A model of environmental governance that is robust, promotes compliance with rules and also has greater business support will generate significant benefits (and opportunities) for Northern Ireland's economy as well as protecting its environment. In the short term, the NIAO should be asked to conduct a review examining the economic impacts of environmental regulation and value for money of public expenditure on the environment in order to clearly demonstrate this link. To further demonstrate this, the PAC might also be asked to produce a report on the long-term opportunities of looking at the economy and the environment in a more joined-up way. By making the links between environmental governance failure and potential economic crisis on one hand and good environmental governance and sustainable economic development on the other, such reports might gain more political traction than they have in the past. With the DUP/Conservative deal creating an intense lack of trust between all major political parties and recent elections demonstrating an apparent reinvigoration of tribal politics, there is growing need and increased demands for evidence-based policy-making in Northern Ireland. ${ }^{212}$ Robust research which provides unequivocal justification for important environmental governance reforms will be increasingly difficult for politicians to ignore, especially as the actual cost of regulatory and policy failures begins to become clear.

In the short to medium term there is a need to enhance public trust in government's environmental protection efforts. One method through which this could be achieved is through the externalisation of the NIEA to a non-departmental public body. Other changes will require more clarity about the role of the environmental regulator, both internally and externally. A consistent message to the public and regulated community about the rules and regulations that the NIEA is tasked with upholding is necessary and this will not happen whilst internal enforcement arrangements are fragmented. Recent efforts within the NIEA have been made to address this issue. However, civil servants are curtailed in the degree to which major decisions are made in the absence of a devolved

211 UK Government, eDoc, electronic duty of care <www.gov.uk/government/groups/edoc-electronic-duty-ofcare $>$.

212 The Alliance for Useful Evidence has run a series of seminars in Northern Ireland in recent years, the most recent of which 'How Can Government Make the Best Use of Evidence' took place in June 2017. A key proposal discussed at this seminar was whether 'an independent What Works Centre for Northern Ireland, aimed directly at supporting policy makers could ease the burden of finding relevant evidence and make up for the lack of local think tanks pumping out timely reports': Alan Meban, 'There is a Question about our Demand for Evidence and Strategy in Politics' (Slugger O’Toole, 20 June 2017) <http://sluggerotoole.com/2017/06/20/there-is-a-question-about-our-demand-for-evidence-and-strategyin-politics $/>$. In addition, The Detail is a not-for-profit investigative news and analysis website which publishes in-depth data and investigations across a range of areas including health, education, politics, justice and crime, government accountability, and the legacy of conflict in Northern Ireland. A recent investigation by The Detail highlighted the cost of regulatory failures in the context of waste disposal, as well as publishing worrying data relating to fires at recycling facilities in the last decade. Campbell (n 104). 
government. ${ }^{213}$ There have clearly been a lot of recommendations given by many different individuals and bodies over the years as to how environmental governance and regulation might be better managed or reformed, but these have not led to many substantive or effective changes in practice. Adopting a new non-departmental public body would be a positive step, but there will be a significantly greater chance of improvements if there is the political will to implement some of the additional governance and regulatory changes (which do not attract as many political headlines), as suggested by experts like Macrory, Bell, Burke, Turner, NGOs and government bodies such as the CJI. As discussed previously in this analysis, these changes must take place across governance structures, law and policy and the delivery of environmental regulation.

Longer-term reforms will depend inherently on Brexit and the shape of the UK's exit deal. Should the UK leave the Single Market and ignite a 'bonfire of regulations', there is a risk that environmental law will be diluted and environmental standards will fall. The effect could be more profound in Northern Ireland where, given the precarious state of the environment, any reduction in environmental regulation could have potentially catastrophic impacts. For example, intensification of agriculture coupled with lax regulation of agricultural pollution could lead to increased degradation of the already at risk aquatic environment - with knock-on effects that include increased water purification costs, eutrophication and damage to protected species and habitats. Whether EU countermeasures are employed to mitigate this risk or whether the UK as a whole instigates measures to prevent fragmentation and divergence in environmental standards across its constituent parts remains to be seen. Significant uncertainty also surrounds the question of whether environmental funding provided to Northern Ireland under EU schemes such as Horizon 2020, LIFE+ and INTERREG will be matched by the devolved or UK governments after Brexit. ${ }^{214}$ Given the uniquely challenging regulatory context, turbulent political context and the historical legacy of environmental governance failures in Northern Ireland, any reform agenda must be able to adapt to ongoing political developments, be based on robust evidence and be designed to deal with the issues faced in this jurisdiction rather than merely trying to 'catch up' with UK or EU standards of protection. In this respect two key avenues may offer opportunities to a more ambitious and long-term programme of environmental governance reform and the viability of these should be explored by government.

Firstly, there is room for engagement in a more thoughtful process of reform regarding use of new environmental policy tools. In Northern Ireland one rare environmental policy success has been the use of the plastic bag tax to reduce the number of plastic bags sent to landfill. The policy has resulted in substantial reductions in the numbers of plastic bags in circulation, as well as generating over $£ 3$ million for environmental improvement projects n 2015/16 alone. ${ }^{215}$ However, there is a need for further engagement with the use of other new and emerging policy innovations, and

213 In April 2017, an Enforcement Branch was set up within the NIEA as a result of internal restructuring. This branch is part of a Resource Efficiency Division and includes Environmental Crime and Financial Investigation sections, but appears to still be separate from the Regulation Unit and Water Management Unit. As of July 2017, the only published details on the internal restructuring are available within a candidate booklet for an advertised vacancy within the NIEA <https://irecruitext.hrconnect.nigov.net/resources/documents/i/r/c/irc214254-cib-(final).pdf $>$.

214 Suzie Cave, Northern Ireland's Environment - Background and Potential Brexit Considerations (Northern Ireland Assembly Briefing Paper 58/16, NIAR 262-16, September 2016) 5.

215 'Minister welcomes sustained reduction in carrier bag use' (25 August 2016) $<$ www.northernireland.gov.uk/news/minister-welcomes-sustained-reduction-carrier-bag-use>. 
critical 'what works' evaluation of the success of existing tools. ${ }^{216}$ For example, although the landfill tax has clearly reduced the amount of waste being disposed of in landfill sites, an unintended consequence has been the creation of a very significant illegal dumping problem across Northern Ireland and its border with the Republic of Ireland. ${ }^{217}$ In addition, research has demonstrated significant problems with the use of criminal sanctions as a response to breaches of environmental law in Northern Ireland. ${ }^{218} \mathrm{~A}$ growing body of literature has examined questions relating to new environmental policy instruments across Europe and valuable lessons may be gained from policy-maker engagement with a broader range of tools and detailed context-specific analysis of the tools currently employed to deliver environmental outcomes in this jurisdiction. ${ }^{219}$ Secondly, enhanced cross-border cooperation to deal with the environmental challenges faced on the island of Ireland could present opportunities to ensure maintenance of EU standards of environmental protection post-Brexit, reduction of unnecessary duplication of regulatory services, streamlining of administrative processes associated with any alteration to the border and prevention of divergent regimes on either side of the border from creating opportunities for environmental crime. There is a constitutional basis for cross-border cooperation on environmental matters enshrined in the Good Friday Agreement. There is also political precedent for the provision of all-island services when there is a clear and pragmatic case for doing so, for example, in the provision of children's clinical services via the all-island Congenital Heart Disease Network and the associated Cross-Jurisdictional Oversight Group. ${ }^{220}$ In addition, there are already important aspects of the environment which are being successfully managed on an all-island basis, for example, close cooperation on river basin management ${ }^{221}$ and in relation to responding to invasive species. ${ }^{222}$ The strong environmental, legal and political drivers for an allisland approach to environmental governance have also been highlighted by the comprehensive Review of Environmental Governance in Northern Ireland undertaken in 2007.223 Applying this approach to environmental governance could present a significant opportunity to re-evaluate the highly criticised approaches that have been adopted on both sides of the border and develop a jointly delivered system that more effectively protects the environment on an all-island basis.

Given the political crisis currently enveloping Northern Ireland's devolved administration and, at the time of writing, little chance of the re-establishment of the Stormont assembly in the short term, it is easy to relegate environmental governance issues down the list of urgent priorities. However, a well-managed environment should be seen as a vital asset for the shared future of the people of Northern Ireland and a greater

216 Andrew Jordan, Rüdiger K W Wurzel and Anthony Zito, 'The Rise of "New" Policy Instruments in Comparative Perspective: Has Governance Eclipsed Government?’ (2005) 53(3) Political Studies 477-96; Andrew Jordan, Rüdiger K W Wurzel, and Anthony R Zito, "New" Instruments of Environmental Governance: Patterns and Pathways of Change’ (2003) 12(1) Environmental Politics 1-24.

217 Brennan (n 2).

218 Brennan (n 28).

219 Rüdiger K W Wurzel, Anthony R Zito and Andrew J Jordan, Environmental Governance in Europe: A Comparative Analysis of the Use of New Environmental Policy Instruments (Edward Elgar 2013).

220 Draft Joint Policy Statement by the Ministers of Health, Simon Harris TD and Michelle O'Neill MLA on the 'All-island Congenital Heart Disease Network' <www.niassembly.gov.uk/assembly-business/officialreport/written-ministerial-statements/department-of-health--all-island-congenital-heart-disease-network/ >.

221 Katie Murphy and Grace Glasgow, 'North-South coordination in Ireland's International River Basin Districts' (2009) 109B Biology and Environment: Proceedings of the Royal Irish Academy 139-50.

222 Invasive Species Ireland is a joint venture between the NIEA and the National Parks and Wildlife Service in the Republic of Ireland. See <http://invasivespeciesireland.com>.

223 Burke et al (n 9). 
focus on protecting this common (not tribal) interest would enhance confidence in power-sharing and demonstrate stability. The importance assigned to environmental protection by the public in Northern Ireland is evident in the high membership numbers of environmental NGOs in Northern Ireland. This indicates that there is clearly an appetite for environmental protection that is currently at odds with the level of importance assigned to it by the previous devolved governments. Ultimately, Northern Ireland's politicians from across the political spectrum must realise the inextricable links between environmental protection, economic development and social well-being and reflect this realisation in government priorities if and when a political settlement is reached. ${ }^{224}$ In the meantime, there is a need for urgent action in order to avoid potentially catastrophic environmental damage and limit the spiralling economic consequences of decades of environmental governance failure.

224 Peter Doran, Jennifer Wallace and John Woods, Measuring Wellbeing in Northern Ireland: A New Conversation for New Times (Carnegie UK Trust 2014). This report addresses well-being, the environment and the peace process and shows the important inter-relationships between these. 
